\title{
Overview of the first HyMeX Special Observation Period over Italy: observations and model results
}

\author{
R. Ferretti ${ }^{1}$, E. Pichelli ${ }^{1}$, S. Gentile ${ }^{1}$, I. Maiello ${ }^{1}$, D. Cimini $^{2,1}$, S. Davolio ${ }^{3}$, M. M. Miglietta ${ }^{4}$, G. Panegrossi ${ }^{5}$, \\ L. Baldini ${ }^{5}$, F. Pasi ${ }^{6,10}$, F. S. Marzano ${ }^{1,7}$, A. Zinzi ${ }^{8}$, S. Mariani ${ }^{9}$, M. Casaioli ${ }^{9}$, G. Bartolini ${ }^{10}$, N. Loglisci $^{11}$, \\ A. Montani ${ }^{12}$, C. Marsigli ${ }^{12}$, A. Manzato ${ }^{13}$, A. Pucillo ${ }^{13}$, M. E. Ferrario ${ }^{14}$, V. Colaiuda ${ }^{1}$, and R. Rotunno ${ }^{15}$ \\ ${ }^{1}$ CETEMPS, Department of Physics, University of L'Aquila, L'Aquila, Italy \\ ${ }^{2}$ Institute of Methodologies for Environmental Analysis, CNR IMAA, Potenza, Italy \\ ${ }^{3}$ Institute of Atmospheric Sciences and Climate, CNR ISAC, Bologna, Italy \\ ${ }^{4}$ Institute of Atmospheric Sciences and Climate, CNR ISAC, Lecce, Italy \\ ${ }^{5}$ Institute of Atmospheric Sciences and Climate, CNR ISAC, Rome, Italy \\ ${ }^{6}$ Institute of Biometeorology, CNR IBIMET, Florence, Italy \\ ${ }^{7}$ Department of Information Engineering, Electronics and Telecommunications DIET, Sapienza University, Rome, Italy \\ ${ }^{8}$ ASI Science Data Center (ASDC), Rome, INAF-OAR, Monte Porzio Catone (Rome) Italy, University of Naples \\ "Parthenope", Naples, Italy \\ ${ }^{9}$ Institute for Environmental Protection and Research, ISPRA, Rome, Italy \\ ${ }^{10}$ LaMMA Consortium, Florence, Italy \\ ${ }^{11}$ ARPA Piemonte - Weather Forecasting Department, Turin, Italy \\ ${ }^{12}$ ARPA Emilia Romagna - SIMC, Bologna, Italy \\ ${ }^{13}$ ARPA Friuli Venezia Giulia - OSMER, Visco (Udine), Italy \\ ${ }^{14}$ ARPA Veneto, Servizio Meteorologico, Teolo (Padua), Italy \\ ${ }^{15}$ NCAR, Boulder, (CO), USA
}

Correspondence to: R. Ferretti (rossella.ferretti@aquila.infn.it)

Received: 31 July 2013 - Published in Hydrol. Earth Syst. Sci. Discuss.: 23 September 2013

Revised: 3 April 2014 - Accepted: 9 April 2014 - Published: 26 May 2014

\begin{abstract}
The Special Observation Period (SOP1), part of the HyMeX campaign (Hydrological cycle in the Mediterranean Experiments, 5 September-6 November 2012), was dedicated to heavy precipitation events and flash floods in the western Mediterranean, and three Italian hydrometeorological monitoring sites were identified: LiguriaTuscany, northeastern Italy and central Italy. The extraordinary deployment of advanced instrumentation, including instrumented aircrafts, and the use of several different operational weather forecast models, including hydrological models and marine models, allowed an unprecedented monitoring and analysis of high-impact weather events around the Italian hydro-meteorological sites. This activity has seen strong collaboration between the Italian scientific and operational communities. In this paper an overview of the Italian organization during SOP1 is provided, and selected Intensive
\end{abstract}

Observation Periods (IOPs) are described. A significant event for each Italian target area is chosen for this analysis: IOP2 (12-13 September 2012) in northeastern Italy, IOP13 (1516 October 2012) in central Italy and IOP19 (3-5 November 2012) in Liguria and Tuscany. For each IOP the meteorological characteristics, together with special observations and weather forecasts, are analyzed with the aim of highlighting strengths and weaknesses of the forecast modeling systems, including the hydrological impacts. The usefulness of having different weather forecast operational chains characterized by different numerical weather prediction models and/or different model set up or initial conditions is finally shown for one of the events (IOP19). 


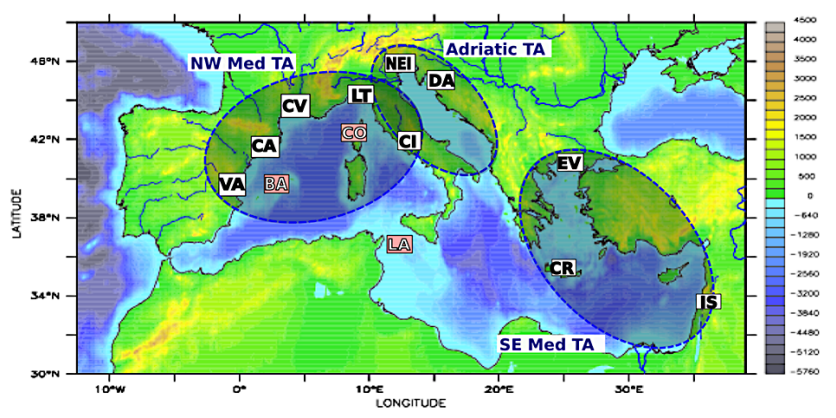

Figure 1. HyMeX target areas (TA) in the Mediterranean basin and hydro-meteorological sites. Liguria-Tuscany (LT), northeastern Italy (NEI) and central Italy (CI) are located within the Italian territory. After Ducrocq et al.,2010

\section{Introduction}

The HYdrological cycle in the Mediterranean Experiment (HyMeX, http://www.hymex.org; Drobinski et al., 2013) is an international experimental program that aims to advance scientific knowledge of water cycle variability in the Mediterranean basin. This goal is pursued through monitoring, analysis and modeling of the regional hydrological cycle in a seamless approach. Its multidisciplinary research activity investigates phenomena on different temporal and spatial scales, from the inter-annual/decadal variability of the Mediterranean coupled system (atmosphere-land-ocean) to the single event of severe weather. In this context special emphasis is given to the topics of Special Observation Period (SOP1), that is the occurrence of heavy precipitation and floods, and the associated impacts on society.

The intense sea-atmosphere interactions were the specific topic of SOP2, which is not addressed in this paper. The characteristics of the Mediterranean region, a nearly closed basin surrounded by both highly urbanized and complex terrain close to the coast, makes the Mediterranean area prone to natural hazards related to the water cycle. These are the reasons for improving our understanding and the predictability of hydro-meteorological hazards in this region. In particular, during the autumn season, when the sea is still relatively warm, the large thermal gradient between the atmosphere and the sea favors intense heat and moisture fluxes (Duffourg and Ducrocq, 2011, 2013), which are the energy source for storms. That is why the Mediterranean is often affected by heavy rainfall and floods in autumn, which are responsible for most of the natural disasters in the region. Hence the interest in improving knowledge and forecasting of disastrous severe weather events is clear for both scientific research and operational activities. Consistent with the HyMeX program, within the Western Mediterranean Target Area (TA) three hydro-meteorological sites were identified over Italy (Fig. 1): Liguria-Tuscany (LT), northeastern Italy (NEI) and central Italy (CI). These sites were selected because they have weather systems representative of those re-

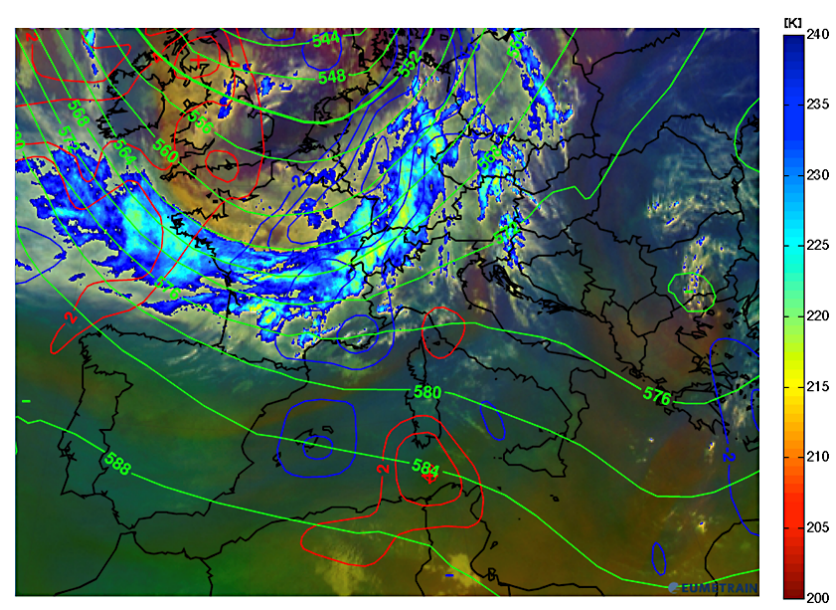

Figure 2. Synoptic analysis over the western Mediterranean region at 06:00 UTC, 12 September 2012: ECMWF $500 \mathrm{hPa}$ geopotential height (green lines), $700 \mathrm{hPa}$ temperature advection (red warm and blue cold), MSG SEVIRI AirMass RGB composite EumetSat product and enhanced IR $10.8 \mu \mathrm{m}$ temperature, ranging between $200 \mathrm{~K}$ (red) and $240 \mathrm{~K}$ (blue). Source: http://www.eumetrain.org.

sponsible for most of the heavy precipitation and flood events affecting the Italian territory, which can be related to specific large-scale patterns (Tartaglione et al., 2009). For example, the severe weather events that occurred over the Alps in recent years (Rotunno and Houze, 2007; Mariani et al., 2009; Barbi et al., 2012) or in Liguria and Lazio during the autumn of 2011 (Buzzi et al., 2012; Ferretti et al., 2012; Parodi et al., 2012; Rebora et al., 2013), are directly (e.g., by orographic precipitation) or indirectly (e.g., by cyclogenesis: see Tibaldi et al., 1990) related to the influence of mountain ranges on atmospheric motions. The steep slopes of the Alps and the Apennines in the vicinity of large coastal areas of the Mediterranean, and the sea itself that acts as a large source of moisture and heat, are the key factors in determining the convergence and the rapid uplift of moist and unstable air responsible for triggering condensation and convective instability processes (Benzi et al., 1997; Rotunno and Ferretti, 2001). Heavy rainfall events are often associated with the development of intense convective systems (Davolio et al., 2009; Melani et al., 2012), which are still not completely understood and are notoriously difficult to predict (Weisman et al., 2008; Ducrocq et al., 2008; Bresson et al., 2012; Miglietta and Rotunno, 2012). Moreover, within several small and densely urbanized watersheds with steep slopes, which characterize the Italian area, precipitation events that persist over the same area for several hours can become devastating floods in a relatively short time (Silvestro et al., 2012; Vulpiani et al., 2012). In addition, it is worth recalling that the national socio-economic impact of these kinds of events is quite important, as indicated by the number of casualties and damages reported (see, e.g., Guzzetti et al., 2005; Lastoria et al., 2006; Salvati et al., 2010, and references therein). 
A key component of HyMeX is the experimental activity based on atmospheric, oceanic and hydrological monitoring for a period of ten years, from 2010 to 2020. Within this time frame, shorter periods of intensive monitoring, named Special Observation Periods (SOPs), were planned. The first field campaign, SOP1 (Ducrocq et al., 2014), dedicated to heavy precipitation and flash floods, took place in autumn 2012 (5 September-6 November) over the western Mediterranean. The second field campaign, named SOP2, was dedicated to intense air-sea exchanges and dense water formation, and took place in winter 2013 (February-March). SOP1 was characterized by an extraordinary deployment of advanced instrumentation, including instrumented aircrafts. In order to prevent or reduce societal losses, progress in the monitoring of and predictive capability for these severe events are needed. This requirement represented the strong motivation that resulted in the large and active participation of the Italian community in the first HyMeX SOP. The activities carried out during the field campaign as well as those planned for the upcoming years represent an important opportunity for exploiting the synergy between a unique database of observations and model simulations, for the study of intense orographic precipitation. Therefore, improvements in the knowledge and forecasting ability of highimpact weather events are expected in the near future. The present study represents a first step towards understanding the scientific issues and coordinating the activity of the large Italian scientific and operational communities in the field.

In this paper SOP1 is presented together with some results. The aim of the paper is twofold:

- to provide a scientific overview of the events that affected the Italian area during SOP1 (Sect. 3) highlighting the hydrological response to the heavy precipitation as well as the full forecast chain (meteo-hydro) and the socio-economic impact;

- to investigate the response of the different operational chains to extreme events for three case studies.

Extraordinary monitoring activities, an outstanding number of implemented weather forecasting modeling chains, and one meteo-hydro and two meteo-hydro-marine chains are described in Sect. 2, highlighting the large Italian community effort for the field campaign in terms of coordination and logistics. The paper by Davolio et al. (2014) describes the organizational efforts and activities of the Italian scientific and operational communities at the Virtual Operational Center, hosted by CETEMPS in L'Aquila during the HyMeX SOP1 campaign, and the consequent impacts in the context of the peculiar organization of meteorology in Italy.

The SOP1 IOPs are presented in Sect. 3 together with observations and forecast results for three selected IOPs. Perspectives for future work are given in Sect. 4.

\section{HyMeX SOP1 activity in Italy: observations and models}

This section summarizes the instrumentation collecting observations and the forecasting modeling chains producing numerical weather predictions during SOP1 in Italy. It must be noted that these include both operational and research instrumentation/models in some cases specifically deployed or implemented for SOP1.

\subsection{Observations}

Three hydro-meteorological sites of interest were identified over Italy (Fig. 1) in the HyMeX Implementation Plan (Ducrocq et al., 2010). The CI hydro-meteorological site is located at the eastern boundary of the HyMeX North West Mediterranean TA and at the western boundary of the Adriatic TA (Fig. 1, CI). The area is densely populated and includes the urban area of Rome, with 4 million inhabitants. The orography of CI is quite complex, going from sea level to nearly $3000 \mathrm{~m}$ in less than $150 \mathrm{~km}$. The CI area involves many rivers, including two major basins: the Aniene-Tiber basin (1000 km long) and the Aterno-Pescara basin $(300 \mathrm{~km}$ long), respectively on the western and eastern side of the Apennines ridge. The instrumentation deployed over the CI area belongs to several institutions, including the CEnter of integration of remote sensing TEchniques and numerical Modeling for the Prediction of Severe weather (CETEMPS), the National Department of Civil Protection (DPC), the Department of Information Engineering, Sapienza University of Rome (DIETSap), the Institute of Atmospheric Sciences and Climate of the National Research Council of Italy (CNR ISAC), HIMET (High Innovation in Meteorology and Environmental Tech., L'Aquila), the University of Ferrara, the National Observatory of Athens (NOA), the US National Aeronautics and Space Agency (NASA), the Abruzzo Regional Government (RegAb), and finally the Italian National Agency for New Technologies, Energy and Sustainable Economic Development (ENEA). The instrumentation deployed over the CI area during SOP1 is summarized in Table 1. Part of this instrumentation is permanent and run operationally. Conversely, several instruments were specifically deployed for the period of SOP1 as a consequence of specific international agreements, such as with NASA and NOA. These include an X-band polarimetric mini-radar, a K-band microrain radar and several disdrometers of three kinds, namely, a 2-D video disdrometer, PLUDIX, and laser Parsivel-2 disdrometers (see Table 1).

The LT hydro-meteorological site is located at the eastern boundary of the HyMeX North West Mediterranean TA (Fig. 1), in a coastal region where the Alpine-Apennine chain is close to the Mediterranean Sea. The high elevation of the mountains - more than 2000 m a.m.s.l. (above mean sea level) - at a few tens of kilometers from the coast illustrates the complex orography of this area, with many densely 
Table 1. Instrumentation deployed over the CI area during SOP1 (in parentheses the responsible institutions).

\begin{tabular}{|c|c|}
\hline Radars & $\begin{array}{l}\text { - } 1 \text { C-band single-polarization radar, Monte Midia, Abruzzo (CETEMPS, } \\
\text { RegAb) } \\
\text { - } 1 \text { C-band polarimetric radar, Il Monte, Abruzzo (DPC) } \\
\text { - } 1 \text { C-band single-polarization radar, Monte Serano, Umbria (DPC) } \\
\text { - } 1 \text { C-band dual-polarization radar, ISAC Atmospheric Observatory, Rome } \\
\text { (CNR ISAC) } \\
\text { - } 1 \text { X-band single-polarization radar, Rome (DIETSap) } \\
\text { - } 1 \text { X-band polarimetric mini-radar, L'Aquila (HIMET, CETEMPS) } \\
\text { - } 1 \text { X-band polarimetric mini-radar, Rome (HIMET) }\end{array}$ \\
\hline Rain gauges & $\sim 200$ telemetered rain gauges and thermometers (Regional authorities) \\
\hline $\begin{array}{l}\text { Disdro } \\
\text { meters }\end{array}$ & $\begin{array}{l}\text { - } 1 \text { Parsivel laser disdrometer (DIETSap) } \\
\text { - } 1 \text { Parsivel laser disdrometer (CNR ISAC) } \\
\text { - } 1 \text { K-band micro-rain radar in Rome (DIETSap, NASA) } \\
\text { - } 1 \text { bidimensional video-disdrometers 2DVD in Rome (DIETSap, NASA) } \\
\text { - } 2 \text { PLUDIX disdrometers at DIETSap and CNR ISAC (University of Ferrara) } \\
\text { - } 5 \text { Parsivel-2 laser disdrometers (Pescara, L'Aquila, Avezzano, CNR ISAC, } \\
\text { CNR-INSEAN) (NASA) }\end{array}$ \\
\hline Soundings & $\begin{array}{l}\text { - } 1 \text { research sounding station at L'Aquila (CETEMPS) } \\
-1 \text { tether sounding (CNR ISAC) } \\
-1 \text { operational sounding site at Pratica di Mare, Rome (CNMCA, Air Force) }\end{array}$ \\
\hline Other & $\begin{array}{l}\text { - } 1 \text { Raman lidar and } 1 \text { ceilometer, located in L'Aquila (CETEMPS) } \\
\text { - } 1 \text { meteo station and VLF lightning sensor in Rome (DIETSap) } \\
\text { - } 2 \text { SODAR (CNR ISAC) at the ISAC Atmospheric Observatory and in the } \\
\text { Castel Porziano Presidential Park } \\
\text { - Micrometeorological surface layer sensors (CNR ISAC) } \\
\text { - AWS surface station (CNR ISAC) } \\
\text { - } 1 \text { aerosol lidar and } 1 \text { ceilometer (CNR ISAC) } \\
\text { - } 3 \text { sunphotometers (CNR ISAC) } \\
\text { - } 1 \text { microwave radiometer (CNR ISAC) } \\
\text { - LINET VLF/LF lightning detection network station (CNR ISAC) } \\
\text { - Weather station near Rome (ENEA) }\end{array}$ \\
\hline
\end{tabular}

populated catchments characterized by steep slopes and limited extents. The Liguria Region Meteo Hydrological Observatory (OMIRL) deployed a ground observation operational network that includes meteorological parameter sensors. ARPA Piemonte and ARPA Liguria manage the C-dual band radar. Over Tuscany, the Hydrological Service, Consorzio LaMMA, and DPC manage a dense network of meteorological stations. All the instruments over the LT area were operational during SOP1 and the Intensive Observation Periods (IOPs), and they are summarized in Table 2.

The northeastern Italy hydro-meteorological site covers an area of almost $40000 \mathrm{~km}^{2}$, including three regions (Veneto, Trentino-Alto Adige, and Friuli Venezia Giulia; Fig. 1, NEI), and is characterized by a multiple river system with the longest rivers of Italy (Po and Adige), a wide flood plain area, and the eastern Alpine range. The orography in this region has a steep terrain with mountain peaks of nearly $4000 \mathrm{~m}$ a.m.s.l., and this type of variable terrain plays a major role in extreme meteorological events. The instrumentation deployed over the NEI area during SOP1 is summa- rized in Table 3 and belongs to several institutions, including OSMER - ARPA FVG, Ufficio Idrologico of Bolzano, MeteoTrentino, ARPAV - Servizio Meteorologico, Areonautica Militare, and Regional Civil Protection in Friuli Venezia Giulia. Most of the instruments run operationally, whereas a few of them were specifically deployed for the period of SOP1, including the mobile X-band polarimetric radar from NOA, a K-band micro-rain radar from NASA, and five disdrometers of two kinds (2DVD and Parsivel) from NOA.

For the whole Italian territory and the three hydrometeorological sites in particular, measurements from the LINET VLF/LF lightning detection network (Betz et al., 2009) with 12 sensors located in Italy were made available by CNR ISAC (Rome branch), providing high-precision threedimensional location and time of occurrence of intra-cloud and cloud-to-ground strokes in real time during the IOPs discussed below.

During the campaign, DPC made available approximately 2600 rain gauges in real time; most of them were operational over Italy, producing an exceptionally well-distributed 
Table 2. Instrumentation deployed over the LT area during SOP1 (in parentheses the responsible institutions).

\begin{tabular}{ll}
\hline Radars & -1 C-band dual polarization radar, Monte Settepani, Liguria (ARPA Piemonte \& ARPA Liguria) \\
& -1 C-band single-polarization radar, Monte Crocione, Tuscany (DPC) \\
\hline Rain gauges & $\sim 520$ telemetered rain gauges (Consorzio LaMMA, OMIRL) \\
\hline Soundings & \\
\hline Other & -1 RASS (radio acoustic sounding system), Florence (Consorzio LaMMA) \\
& -45 stream level gauges (OMIRL) \\
& -131 hydrometers (Consorzio LaMMA) \\
& -190 thermometers (Consorzio LaMMA) \\
& -209 anemometers (Consorzio LaMMA) \\
& -156 hygrometers (Consorzio LaMMA) \\
&
\end{tabular}

Table 3. Instrumentation deployed over the NEI area during SOP1 (in parentheses the responsible institutions). FVG stands for Friuli Venezia Giulia.

\begin{tabular}{ll}
\hline Radars & -1 C-band dual-polarization radar, Fossalon di Grado, FVG (FVG Regional Civil Protection) \\
& -1 C-band single-polarization radar, Monte Macaion, Trentino-Alto Adige (Meteotrentino) \\
& -1 C-band single-polarization radar, Monte Grande, Veneto (ARPAV) \\
& -1 C-band single-polarization radar, Concordia Sagittaria, Veneto (ARPAV) \\
& -1 mobile X-band polarimetric radar, Trafoi, Trentino-Alto Adige (NOA) \\
\hline Rain gauges & $\sim 400$ telemetered tipping bucket rain gauges (FVG Regional Civil Protection, ARPAV) \\
\hline Disdrometers & -5 disdrometers: 3 Parsivels, 1 2DVD (NOA) and 1 micro-rain radar (NASA) \\
\hline Soundings & -1 operational sounding site at Campoformido, Udine (CNMCA) \\
\hline Other & -2 microwave radiometers in Padua and Rovigo (ARPAV) \\
& -4 SODAR (ARPA Veneto) \\
& -55 hydrometric stations (FVG Regional Civil Protection, ARSO Slovenia) \\
\hline
\end{tabular}

coverage for the rain measurements (see Fig. 2 in Davolio et al., 2014). Such a richness of surface stations had never been available before in a monitoring and forecasting campaign.

To complement the ground-based observations, instrumented aircrafts were deployed by the HyMeX international team. This is a crucial element of the HyMeX observational strategy for various reasons: (i) heavy precipitation events (HPE) may occur outside the hydro-meteorological sites and may not be adequately observed without aircraft, (ii) HPE are often related to offshore events and/or synoptic-scale systems extending at least partially over the sea, (iii) in situ measurements are critically needed to assess and/or validate some of the products derived from the ground-based observation systems, (iv) while ground-based systems provide continuity in time, aircraft allow high temporal and spatial resolution measurements. Therefore, three instrumented aircrafts were deployed by the HyMeX French and German teams, and thus airborne measurements were available occasionally during IOPs over Italy. The following aircraft were available for the North Western Mediterranean TA:
- SAFIRE FALCON 20 (France) (F20 hereinafter)

- Payloads: RASTA radar, cloud microphysics sensors, dropsondes

- SAFIRE ATR-42 (France)

- Water vapor lidar, cloud microphysics sensors, aerosol probe

- KIT 128 (Germany) (DO128 hereinafter)

- In situ sensors, turbulent fluxes, radiation, dropsondes

The DO128 and ATR42 were used to sample the upwind low-level flow, focusing on the pre-convective environment during the initiation phase. The F20 was used to observe the precipitating systems during the mature phase with its microphysical probes and radar systems.

Within the northwestern Mediterranean domain, the airspace is controlled by several distinct authorities with different constraints with respect to the HyMeX aircraft flights. Well in advance of SOP1, the procedures for each aircraft 
were defined with the respective air traffic control authorities (HyMeX Operation Plan SOP1, 2012). In the flight information regions (FIR) over Italy, these included four flight plans for ATR42 and two flight plans for F20, while twelve flight patterns for the DO128 over Corsica (within the French FIR) were also of some interest for soundings of the upstream flow over Italy.

\subsection{Numerical weather prediction models}

In the framework of HyMeX SOP1 a common platform has been implemented to upload products from different numerical weather prediction (NWP) and hydrological models (available online at http://sop.hymex.org). These have been a fundamental means for the forecasting activity during the campaign, allowing for planning with adequate advance notice the observation strategy of the events of interest.

The Italian community made available several models in use by the different groups participating in the experiment. This provided the possibility of having many products available to refer to during the forecasting phase at the Italian operational center organized in L'Aquila that supported the HyMeX Operational Center (HOC) in Montpellier (France), as well as to compare performances of different models and thus investigate their strengths or deficiencies.

The abundance of operational weather prediction models turned out to be of great help especially for the most difficult task, i.e., making decisions on the take-off time for the flights measuring hydro particles in well-developed convective cells.

Basically three different weather forecast operational chains based on the following high-resolution models were used: the Advanced Research version of the Weather Research and Forecasting (WRF-ARW) used by CETEMPS (WRF-CETEMPS), by CNR ISAC (WRF-ISAC) and by LaMMA (WRF-LaMMA); the BOlogna Limited Area Model (BOLAM) and the MOLOCH model both used by CNR ISAC (respectively BOLAM-ISAC and MOLOCHISAC), by ISPRA (respectively BOLAM-ISPRA and MOLOCH-ISPRA) and by ARPA Liguria; and the COSMO model used by ARPA - SIMC producing the only limitedarea ensemble forecasts available for Italy. In addition, one meteo-hydro chain and two hydro-meteo-marine chains were operational during the campaign forced by WRF-ARW and BOLAM output, respectively.

A short description of the model characteristics and the different implementation schemes used during SOP1 is given in the next sections.

\subsubsection{WRF-ARW}

Several operational chains using the WRF-ARW model were implemented during HyMeX; they differ either by physical model configuration or domains and resolution. The WRFARW model is a numerical weather prediction system that is the result of a joint effort between different research institutes coordinated by the National Center for Atmospheric Research (NCAR, http://www.wrf-model.org). It solves the fully compressible, non-hydrostatic Euler equations, using the terrain-following, hydrostatic-pressure vertical coordinate with vertical grid stretching. It is based on time-split integration using a second- or third-order Runge-Kutta scheme with smaller time steps for acoustic and gravity-wave modes. The horizontal grid is a staggered Arakawa-C. A variety of schemes are provided for the model physics. For further details, the reader is referred to Skamarock et al. (2008).

CETEMPS, CNR ISAC and Consorzio LaMMA use WRF-ARW, but different operational chains are implemented. A nest-down configuration with two domains running independently and 37 vertical levels, with the first level at approximately $30 \mathrm{~m}$ above the ground and unequally spaced distribution to achieve higher density in the PBL, is used at CETEMPS (http://skynet.phys.uniroma1.it/Main_ index.htm). The low-resolution domain $(12 \mathrm{~km})$ covers Italy and part of the Mediterranean basin; it is initialized using ECMWF analysis at 0.125 degrees. The highest resolution domain $(3 \mathrm{~km})$ covers Italy and is initialized by the WRF simulation at $12 \mathrm{~km}$. The new Thompson microphysics scheme with six different hydrometeor categories is used (Thompson et al., 2008) together with a Mellor-Yamada 2.5 turbulence closure scheme (Janjic, 2002; Mellor and Yamada, 1982) for the planetary boundary layer (PBL) parameterization. No cumulus parametization is used at the finer resolution. Details of the chain configuration are in Table 4 . Moreover, specifically for the campaign, the output of WRF-ARW was used to force the Cetemps Hydrological model (CHyM, Coppola et al., 2007), implemented over several major Italian river catchments. This meteorologicalhydrological model chain was used operationally to issue severe weather and hydrological alerts. For example, the severe conditions forecast for 14 September, which one day ahead led to a call for the IOP4 briefly described in the next section, caused major flash floods in central Italy.

Two daily runs (00:00 and 12:00 UTC) with a two-domain, one-way nested configuration initialized using GFS forecasts are operational at CNR ISAC. The parent domain has a horizontal resolution of $15 \mathrm{~km}, 3 \mathrm{~km}$ for the innermost one; 40 vertical levels are used with the first level at approximately $25 \mathrm{~m}$ above the ground and unequally spaced distribution to achieve higher density in the PBL. The same microphysical and boundary layer schemes as WRF-CETEMPS are used. The Kain (2004) cumulus parameterization is used only for the coarser grid (http://meteo.le.isac.cnr.it), that is, no cumulus convective scheme is used for the innermost domain.

At Consorzio LaMMA two independent configurations are run daily at 12 and $3 \mathrm{~km}$ resolutions. The coarse domain (configuration 1 in Table 4) is initialized at 00:00 and 12:00 UTC using GFS analysis and the boundary conditions are upgraded every $6 \mathrm{~h}$. The domain covers central Europe $(200 \times 300$ grid points); 40 vertical levels and 
Table 4. Summary of the main characteristics of the model chains used by the different institutions for SOP1. The COSMO number of members is given in the brackets. The last column indicates whether the model calculates the convection explicitly ("Yes") or uses a convective scheme ("No").

\begin{tabular}{|c|c|c|c|c|c|}
\hline Model [Chain] & $\begin{array}{r}\text { Grid } \\
\text { spacing }(\mathrm{km})\end{array}$ & $\begin{array}{l}\text { Initial } \\
\text { conditions }\end{array}$ & $\begin{array}{l}\text { Boundary } \\
\text { conditions }\end{array}$ & $\begin{array}{l}\text { Forecast } \\
\text { range }\end{array}$ & $\begin{array}{l}\text { Explicit } \\
\text { convection }\end{array}$ \\
\hline WRF-CETEMPS [1] & 12 & ECMWF 12:00 UTC & ECMWF forecasts & $96 \mathrm{~h}$ & No \\
\hline WRF-CETEMPS [1] & 3 & WRF 12 km 00:00 UTC & WRF $12 \mathrm{~km}$ forecasts & $48 \mathrm{~h}$ & Yes \\
\hline WRF-ISAC [1 \& 2] & 15 & GFS 00:00 \& 12:00 UTC & GFS forecasts & $48 \mathrm{~h}$ & No \\
\hline WRF-ISAC [1 \& 2] & 3 & GFS 00:00 \& 12:00 UTC & WRF $15 \mathrm{~km}$ forecasts & $48 \mathrm{~h}$ & Yes \\
\hline WRF-LAMMA [1] & 12 & GFS 00:00 \& 12:00 UTC & GFS forecasts & $120 \mathrm{~h}$ & No \\
\hline WRF-LAMMA [2] & 3 & ECMWF 00:00 \& 12:00 UTC & ECMWF forecasts & $60 \mathrm{~h}$ & Yes \\
\hline BOLAM-ISAC [1] & 11 & GFS 00:00 UTC & GFS forecasts & $72 \mathrm{~h}$ & No \\
\hline MOLOCH-ISAC [1] & 2.3 & BOLAM 03:00 UTC & BOLAM forecasts & $45 \mathrm{~h}$ & Yes \\
\hline BOLAM-ISAC [2] & 9 & GFS 18:00 UTC & GFS forecasts & $54 \mathrm{~h}$ & No \\
\hline MOLOCH-ISAC [2] & 1.5 & BOLAM 00:00 UTC & BOLAM forecasts & $48 \mathrm{~h}$ & Yes \\
\hline BOLAM-ISPRA [1] & 33 & ECMWF 12:00 UTC of d-1 & ECMWF forecasts & $84 \mathrm{~h}(+12$ to $+96 \mathrm{~h})$ & No \\
\hline BOLAM-ISPRA [1] & 11 & BOLAM 00:00 UTC & BOLAM forecasts & $84 \mathrm{~h}$ & No \\
\hline BOLAM-ISPRA [2] & 7.8 & ECMWF 12:00 UTC of d-1 & ECMWF forecasts & $48 \mathrm{~h}(+12$ to $+60 \mathrm{~h})$ & No \\
\hline MOLOCH-ISPRA [2] & 2.5 & BOLAM 00:00 UTC & BOLAM forecasts & $48 \mathrm{~h}$ & Yes \\
\hline COSMO-LEPS (members: 16) & 7 & $\begin{array}{l}\text { ECMWF-EPS members } \\
\text { (00:00 and 12:00 UTC) }\end{array}$ & ECMWF-EPS members & $132 \mathrm{~h}$ & No \\
\hline COSMO-H2-EPS (members: 10) & 2.8 & $\begin{array}{l}\text { COSMO-LEPS members } \\
\text { (12:00 UTC) }\end{array}$ & COSMO-LEPS members & $36 \mathrm{~h}$ & Yes \\
\hline
\end{tabular}

a convective scheme are used; it provides $120 \mathrm{~h}$ forecasts. The fine-resolution domain $(3 \mathrm{~km})$ is initialized at 00:00 and 12:00 UTC using ECMWF high-resolution $\left(0.125^{\circ}\right)$ analysis and the boundary conditions are upgraded every $6 \mathrm{~h}$. It covers the Italian area $(400 \times 440$ grid points) using 35 equally spaced vertical levels, the first level being at $35 \mathrm{~m}$; no convective scheme is used at this resolution. The same microphysical and boundary layer schemes as WRF-CETEMPS are used. The $3 \mathrm{~km}$ domain provides a $60 \mathrm{~h}$ forecast (http: //www.lamma.rete.toscana.it/meteo/modelli).

\subsubsection{BOLAM and MOLOCH}

The BOLAM hydrostatic model (Buzzi et al., 1994; Malguzzi and Tartaglione, 1999) and the MOLOCH nonhydrostatic model (Malguzzi et al., 2006) were developed at CNR ISAC and together constitute a forecasting chain, with MOLOCH nested (one-way) into BOLAM. The horizontal grid is a staggered Arakawa-C; MOLOCH integrates the fully compressible set of equations, with an explicit representation of convective phenomena, deploying a hybrid terrain-following coordinate, relaxing smoothly to horizontal surfaces. Fifty vertical levels are used with the first one at $72 \mathrm{~m}$ above the ground with approximately eight layers within the PBL.

The physical schemes for the two models are almost the same for atmospheric radiation (a combination of the Ritter and Geleyn and ECMWF schemes), sub-grid turbulence (E1 closure), water cycle microphysics (Drofa and Malguzzi, 2004), a soil model with vegetation, as well as the same 3-D Eulerian weighted averaged flux (WAF) scheme for advection. The Kain-Fritsch parameterization scheme is imple- mented in BOLAM for cumulus convection, whereas convection is explicitly computed in MOLOCH. Further details are available at http://www.isac.cnr.it/dinamica/projects/ forecasts.

Several forecasting chains based on BOLAM-MOLOCH have been implemented for SOP1. At CNR ISAC two different chains, having different horizontal grid spacings (Table 4), were initialized at 18:00 and 00:00 UTC, both driven by the GFS global model. At ISPRA, a BOLAM-MOLOCH chain was specifically implemented for SOP1 (Table 4). This chain was initialized using $0.15^{\circ}$ ECMWF analyses and forecasts at 12:00 UTC. In addition, the ISPRA chain currently operational within the SIMM (Sistema Idro-MeteoMare) forecasting system (Speranza et al., 2007; Casaioli et al., 2013b; http://www.isprambiente.gov.it/pre_meteo/simm. $\mathrm{html}$ ) was also provided. This chain is based on BOLAM using two (one-way) nested domains (Table 4) and is driven by ECMWF analysis at $0.5^{\circ}$ resolution at 12:00 UTC. Although different, all the BOLAM domains deployed in the ISPRA chains include the whole Mediterranean basin. Both ISAC-CNR and ISPRA meteorological suites were also used to force two versions of the Shallow water HYdrodynamic Finite Element Model (SHYFEM, Umgiesser et al., 2004) that were operational within the ISMAR-CNR KASSANDRA (Ferrarin et al., 2012) and the ISPRA Hydro-MeteoMarine Forecasting System (SIMM), respectively, to produce storm surge forecasts for the Mediterranean Sea. In addition, outputs of the two ISPRA meteorological suites were deployed for feeding the SIMM Mediterranean-embedded Costal WAve Forecasting system (Mc-WAF, Inghilesi et al., 2012), which has been operational since September 2012. 


\subsubsection{COSMO}

COSMO is the limited-area model used by the COSMO consortium (http://www.cosmo-model.org) and is based on the primitive hydro-thermodynamical equations for a compressible non-hydrostatic flow in a moist atmosphere with no scale approximations (for an overview of COSMO, the reader is referred to Steppeler et al., 2003).

In the framework of HyMeX, two ensemble systems based on the COSMO model were provided by ARPA - SIMC:

- COSMO-LEPS (COSMO Limited-area Ensemble Prediction System) is the operational limited-area ensemble prediction system of the COSMO consortium, running on a daily basis since 2002 (Montani et al., 2011). It is a convective-parameterized ensemble and is run twice a day (starting at 00:00 and 12:00 UTC) at $7 \mathrm{~km}$ using 40 vertical levels, with the first levels approximately $20 \mathrm{~m}$ above the ground, and a forecast range of $132 \mathrm{~h}$. It is composed of 16 members, with initial and boundary conditions taken from elements of ECMWF EPS selected via a clustering analysis-selection technique.

- COSMO-H2-EPS (COSMO HyMeX $2.8 \mathrm{~km}$ Ensemble Prediction System) is a research ensemble system designed for the HyMeX program (Marsigli et al., 2013); COSMO-H2-EPS is an atmospheric convectionpermitting ensemble (i.e., no convective scheme is used) and is run once a day (starting at 12:00 UTC) at $2.8 \mathrm{~km}$ using 50 vertical levels, with the first level approximately $20 \mathrm{~m}$ above the ground, and a forecast range of $36 \mathrm{~h}$. It is composed of 10 members, which take initial and boundary conditions from the first 10 COSMOLEPS members.

Both COSMO-LEPS and COSMO-H2-EPS also benefit from model perturbations applied by varying a few parameters of the COSMO physical schemes.

\section{SOP1: the intense observing periods}

The first field campaign (SOP1, Ducrocq et al., 2013) of the HyMeX project was dedicated to heavy precipitation and flash floods; it took place in autumn 2012 (5 September6 November) over the western Mediterranean area. During SOP1 twenty IOPs were declared, 9 of which occurred in Italy (Table 5), and one of them caused floods on the eastern coast of CI. During the campaign two main features affected the large-scale regime of the Mediterranean region: a negative North Atlantic Oscillation (NAO) index for most of the time and the long-lasting life of Hurricane Nadine (Calas et al., 2013).

The permanent Icelandic Low and Azores High control the direction and strength of westerly winds into Europe. The relative strengths and positions of these systems vary from year to year and this variation is known as the NAO. The station-based index of the NAO has been based on the difference in normalized sea level pressure (SLP) between Lisbon, Portugal (or Ponta Delgada, Azores) and Stykkisholmur/Reykjavik, Iceland since 1864 . Through east-west oscillation motions of the Icelandic Low and the Azores High, it controls the strength and direction of westerly winds and storm tracks across the North Atlantic. A large difference in the pressure at the two stations $(\mathrm{NAO}+)$ leads to increased westerlies and, consequently, cool summers and mild and wet winters in central Europe and its surrounding Atlantic area. If the index is low (NAO-), westerlies are suppressed. Hence, central Europe and the surrounding areas suffer from cold winters and storms tracks are shifted south toward the Mediterranean Sea, increasing storm activity and rainfall in southern Europe and North Africa.

During SOP1, a small positive or generally negative NAO made the weather regime favorable for precipitating systems over southern Europe, whereas Hurricane Nadine strongly reduced the long-term predictability for the first month of the campaign. From the water vapor supply point of view, all the events were characterized by a prevailing cyclonic condition before the events. Based on Duffourg and Ducrocq (2011, 2013), the contribution to the water supply from the sea surface evaporation is expected to be reduced with respect to anticyclonic conditions.

During the campaign several troughs entered the western Mediterranean and swept through the Italian regions after having affected Spain and/or France; only a few events produced cyclogenesis over the Gulf of Genoa or a deep trough over the Tyrrhenian Sea (IOP13, IOP16c, IOP18). Smooth troughs entering the western Mediterranean Sea were often observed producing a westerly-southwesterly flow over Italy (IOP2, IOP6, IOP7b, IOP12, IOP19); occasionally a mesoscale low-pressure system developed associated with a potential vorticity (PV) anomaly (IOP4, IOP16a). It is well known that the lateral translation of an elongated north-south aligned PV streamer produces favorable conditions for heavy precipitation on the southern side of the Alpine ridge (Massacand et al., 1998). Similarly to most of the events, IOP4 and IOP16a were fairly well forecast; however, IOP4 (14 September 2012) was characterized by low predictability of the exact position of the heaviest precipitation, which was highlighted by the large variability among the model forecasts. A cut-off low over the Tyrrhenian Sea and a Bora wind on the Adriatic Sea produced persistent rain throughout the day, reaching maxima of over $150-200 \mathrm{~mm} / 24 \mathrm{~h}$ during 14 September. More than $150 \mathrm{~mm}$ was registered in a few hours over coastal areas, causing several river overflows and the flooding of dense urban areas (Pescara, including the city hospital). The hydro-meteorological chain by $\mathrm{CHyM}$ forecast the event well a few days in advance. Note that the regional branch of DPC, which was part of the Italian operational center in L'Aquila, included this event in their guidelines for a hydro-meteorological decision support system 
Table 5. Summary of the Italian IOPs during SOP1. In the table the affected hydro-meteorological sites, the duration, the instruments specifically activated, and the flight and extra soundings (RS) are reported.

\begin{tabular}{|c|c|c|c|c|c|}
\hline IOPs & Target area & Duration & $\begin{array}{l}\text { Instruments } \\
\text { (except operational) }\end{array}$ & Flight & Extra RadioSoundings \\
\hline IOP2 & $\begin{array}{l}\text { NEI (HPE) } \\
\text { LT (ORP) }\end{array}$ & 12-13 Sep & $\begin{array}{l}\text { Disdrometer and } \\
\mathrm{X} \text {-band radar }\end{array}$ & ATR42 (Italy4) & $\begin{array}{l}\text { Bologna } \\
\text { Udine } 12 \text { Sep at 05:30 UTC }\end{array}$ \\
\hline IOP4 & $\begin{array}{l}\text { CI } \\
\text { (HPE/FFE) }\end{array}$ & $14 \mathrm{Sep}$ & $\begin{array}{l}\text { Radar, sodar and } \\
\text { microwave sensor }\end{array}$ & $\begin{array}{l}\text { Dornier Flight } \\
\text { (Corsica 5) }\end{array}$ & $\begin{array}{l}\text { L'Aquila } 13 \text { Sep at 18:00 UTC, } \\
\text { 14 Sep at 12:00 and 18:00 UTC }\end{array}$ \\
\hline IOP6 & $\begin{array}{l}\text { LT \& NEI } \\
(\text { ORP) }\end{array}$ & 23-24 Sep & $\begin{array}{l}\text { Disdrometer and } \\
\text { X-band radar }\end{array}$ & $\begin{array}{l}\text { Dornier Flight } \\
\text { (Corsica 9) }\end{array}$ & $\begin{array}{l}\text { Data targeting system (DTS) } \\
\text { 23/09:00-18:00 UTC Milan, Rome, } \\
\text { Trapani, Cagliari, Udine } \\
\text { 24/09:00-06:00 UTC: Milan, Trapani, } \\
\text { Cagliari } \\
\text { 24/09:00-18:00 UTC: Udine, Milan, } \\
\text { Rome, Trapani }\end{array}$ \\
\hline IOP7b & $\begin{array}{l}\text { LT (HPE) } \\
\text { NEI (ORP) }\end{array}$ & 26-27 Sep & $\begin{array}{l}\text { Disdrometer and } \\
\mathrm{X} \text {-band radar }\end{array}$ & & $\begin{array}{l}\text { Data targeting system (DTS) } \\
\text { 25/09:00-18:00 UTC: Cagliari } \\
\text { 26/09:00-06:00 UTC: Cagliari } \\
\text { 26/09:00-18:00 UTC Udine } \\
\text { 27/09:00-06:00 UTC Udine }\end{array}$ \\
\hline IOP12a & $\begin{array}{l}\mathrm{LT} \& \mathrm{CI} \\
(\mathrm{HPE})\end{array}$ & $11-12$ Oct & $\begin{array}{l}\text { Radar Polar } 55 \\
\text { (Rome Tor Vergata } \\
\text { - CNR ISAC), sodar, } \\
\text { MW sensors }\end{array}$ & $\begin{array}{l}\text { Falcon-DLR } \\
\text { ATR42 (Italy3) }\end{array}$ & $\begin{array}{l}\text { Bologna } 11 \text { at } 12: 00 \text { UTC and } 12 \\
\text { at 12:00 UTC } \\
\text { L'Aquila } 11 \text { at 16:00 UTC and } 12 \\
\text { at 09:00 UTC }\end{array}$ \\
\hline IOP13 & $\begin{array}{l}\text { LT, NEI \&CI } \\
\text { (HPE) }\end{array}$ & $15-16$ Oct & $\begin{array}{l}\text { Radar Polar } 55 \\
\text { (Rome Tor Vergata } \\
\text { - CNR ISAC), sodar, } \\
\text { MW sensors }\end{array}$ & $\begin{array}{l}\text { ATR42 (Italy1) \& } \\
\text { FALCON (CI) }\end{array}$ & $\begin{array}{l}\text { L'Aquila } 15 \text { Oct at 12:00 UTC } \\
\text { Udine } 15 \text { Oct at 06:00 and 18:00 UTC } \\
\text { Bologna } 15 \text { Oct at 12:00 UTC }\end{array}$ \\
\hline $\begin{array}{l}\text { IOP16a- } \\
\text { IOP16c }\end{array}$ & $\begin{array}{l}\text { LT, NEI \& CI } \\
\text { (HPE/ORP) }\end{array}$ & $26-29$ Oct & $\begin{array}{l}\text { Radar Polar } 55 \\
\text { (Rome Tor Vergata } \\
\text { - CNR ISAC), sodar, } \\
\text { MW sensors }\end{array}$ & $\begin{array}{l}\text { ATR42 (Italy1) \& } \\
\text { FALCON (CI) }\end{array}$ & $\begin{array}{l}\text { L'Aquila } 25 \text { Oct at 16:00 UTC } \\
28 \text { at 18:00 UTC } \\
\text { Udine every } 6 \mathrm{~h} \text { from } 25 \text { Oct at } \\
\text { 18:00 UTC till } 28 \text { Oct at 12:00 UTC } \\
\text { Bologna at 00:00 UTC and 12:00 UTC } \\
\text { from } 26 \text { to } 29 \text { Oct at 00:00 UTC }\end{array}$ \\
\hline IOP18 & $\begin{array}{l}\text { LT, NEI \& CI } \\
(\mathrm{HPE})\end{array}$ & 31 Oct-1 Nov & $\begin{array}{l}\text { Radar Polar } 55 \text { (Rome } \\
\text { Tor Vergata } \\
\text { - CNR ISAC), sodar, } \\
\text { MW sensors }\end{array}$ & $\begin{array}{l}\text { ATR42 (modified } \\
\text { Italy3) \& } \\
\text { FALCON (CI) }\end{array}$ & $\begin{array}{l}\text { L'Aquila } 31 \text { Oct at 12:30 UTC } \\
\text { 16:30 UTC (ending quickly) } \\
\text { 20:30 UTC } \\
\text { Udine, Bologna }\end{array}$ \\
\hline IOP19 & $\begin{array}{l}\text { LT(ORP/HPE) \& } \\
\text { NEI (ORP) }\end{array}$ & $3-5 \mathrm{Nov}$ & 2 BLP balloon & $\begin{array}{l}\text { ATR42 (Hymex 10) \& } \\
\text { FALCON (LT) }\end{array}$ & $\begin{array}{l}\text { Udine } 4 \text { Nov at 18:00 UTC } \\
5 \text { Nov at 06:00 UTC }\end{array}$ \\
\hline
\end{tabular}

(AdriaRadNet REPORT ACTION 3.1, 2013). The hydrological aspects of this event are discussed in more detail by a paper currently in preparation (Tomassetti et al., 2014). The SHYFEM forecasts were useful to investigate the tide peak events that occurred over the Venice Lagoon ("acqua alta" or high water) during IOP16, where the sea level exceeded twice the warning level (more than $120 \mathrm{~cm}$ on $27-28$ October 2012), and IOP18, where the sea level exceeded once the alarm level (more than $140 \mathrm{~cm}$ on 1 November 2012). Preliminary results on the SHYFEM performance during IOP16 and IOP18 are presented in the studies by Casaioli et al. (2013a) and Mariani et al. (2014).
Several events were characterized by convection over the sea followed by orographic precipitation: during IOP2 (1213 September 2012) convection developed over the northern Adriatic, then warm and moist advection from the south produced precipitation inland; during IOP13 (14-16 October 2012) convection associated with a convergence line entered CI from the Tyrrhenian Sea; during IOP19 (3-5 November 2012) southerly advection of warm and humid air produced both convection over the Ligurian Sea and orographic precipitation along the Maritime Alps. In this study, these three events will be analyzed from both observing and modeling points of view. These IOPs have been chosen because of the 


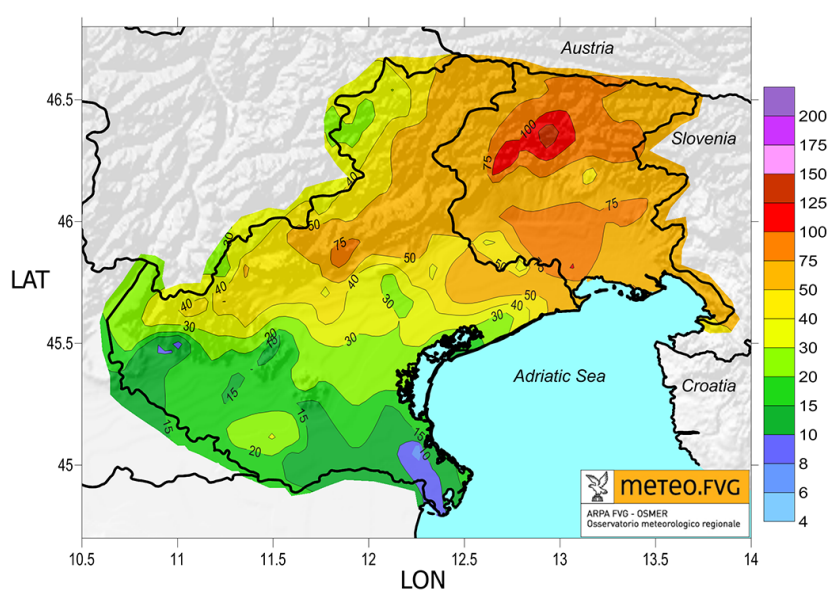

Figure 3. $24 \mathrm{~h}$ accumulated precipitation (color bar in $\mathrm{mm}$ ) for 12 September 2012, obtained from hourly raingauge data analyzed with the natural neighbor method: 163 stations in the Veneto region (ARPAV) and 111 stations in the Friuli Venezia Giulia region (OSMER-ARPA FVG). The figure is courtesy of A. Cicogna (OSMER - ARPA FVG).

density of observations. Specifically, flights from ATR42 and Falcon took place for each of them, providing measurements of the PBL and the cloud microphysics.

\subsection{IOP 2 - NEI}

IOP2 occurred on 12-13 September 2012, involving mostly northeastern Italy. The event was characterized by an NAO index close to zero (0.2); consequently weaker westerlies occurred favoring the storm tracks to cross the Mediterranean area. In the following sections the meteorological characteristics of the event are described.

\subsubsection{Synoptic situation}

A smooth ridge extending from Scandinavia to the entire Mediterranean basin characterized the days before IOP2 (10 - 11 September 2012). During the following two days, the intrusion of a North Atlantic trough from the west weakened and pushed eastward the ridge, producing moist and cold polar air advection toward northern Italy. On 12 September, at 06:00 UTC, a shallow cyclone developed over the Gulf of Genoa and moved northeastward. At the same time on the eastern side of NEI the potential instability increased because of dry air aloft, as shown by the reddish area in the northern Adriatic Sea (Fig. 2), and warm and moist air at the surface advected by a moderate southerly surface wind on the Adriatic Sea blowing toward the eastern part of the Po Valley (Fig. 4a). Indeed, the lower layer of the atmosphere was destabilized, as confirmed by both observations (Fig. 4) and high-resolution weather forecasts (Fig. 5a, b). In the afternoon, a significant pressure gradient, associated with a surface depression, occurred because of a low-tropospheric

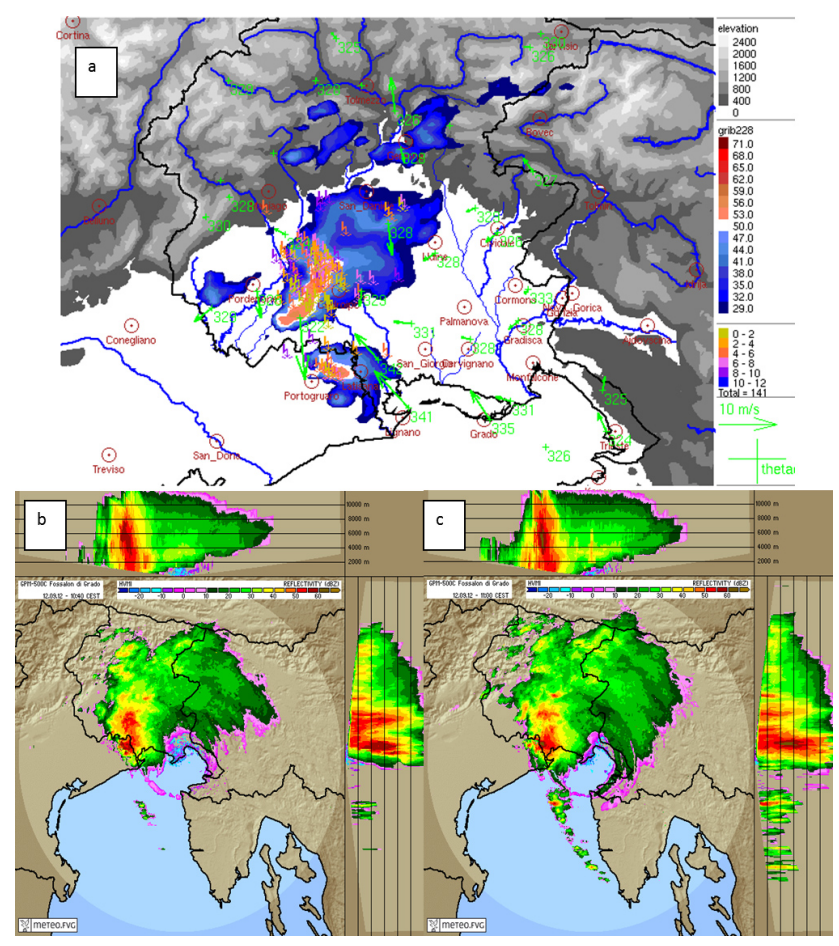

Figure 4. Radar measurements on 12 September 2012: (a) vertical maximum intensity (VMI, filled colors grib228) of the reflectivity by the Fossalon di Grado radar at 08:20 UTC with surface observations (wind vectors and $\Theta_{\mathrm{e}}$ in green) at 08:25 UTC and the C2G lightning (color) strikes in the previous 12 minutes (courtesy of CESI-SIRF), terrain elevation in shaded grey color; (b) VMI with lateral projections at 08:40 UTC; (c) VMI with lateral projections at 09:00 UTC.

cold advection on the northern side of the Alps, which triggered northerly winds descending along the Alpine slopes and spreading into the eastern Po Valley during the passage of the cold front. Most of the operational high-resolution weather forecasts predicted (not shown) this scenario. It is worth noting that in the three previous days a positive sea surface temperature anomaly of $1.5^{\circ} \mathrm{C}$ was recorded over the northern Adriatic Sea (as observed at the Trieste meteorological station).

\subsubsection{Observations}

During 12 September 2012, several convective cells developed in the eastern part of Veneto and in the plain of Friuli Venezia Giulia (FVG hereafter). Figure 3 shows the areal distribution of the accumulated daily rainfall recorded in the Veneto region (source ARPAV) and in the FVG region (source OSMER - FVG): a maximum of $97 \mathrm{~mm} / 24 \mathrm{~h}$ $\left(53 \mathrm{~mm} \mathrm{~h}^{-1}\right.$ between 13:00 and 14:00 UTC) was recorded at Crespano del Grappa $\left(45.5028^{\circ} \mathrm{N}, 11.5027^{\circ} \mathrm{E}\right)$. On the mountain side a small area (Fig. 3, dark red) of precipitation exceeding $150 \mathrm{~mm}$ in $24 \mathrm{~h}$ is clearly shown, whereas the surface rain intensity (SRI) retrieved by the Fossalon di Grado 

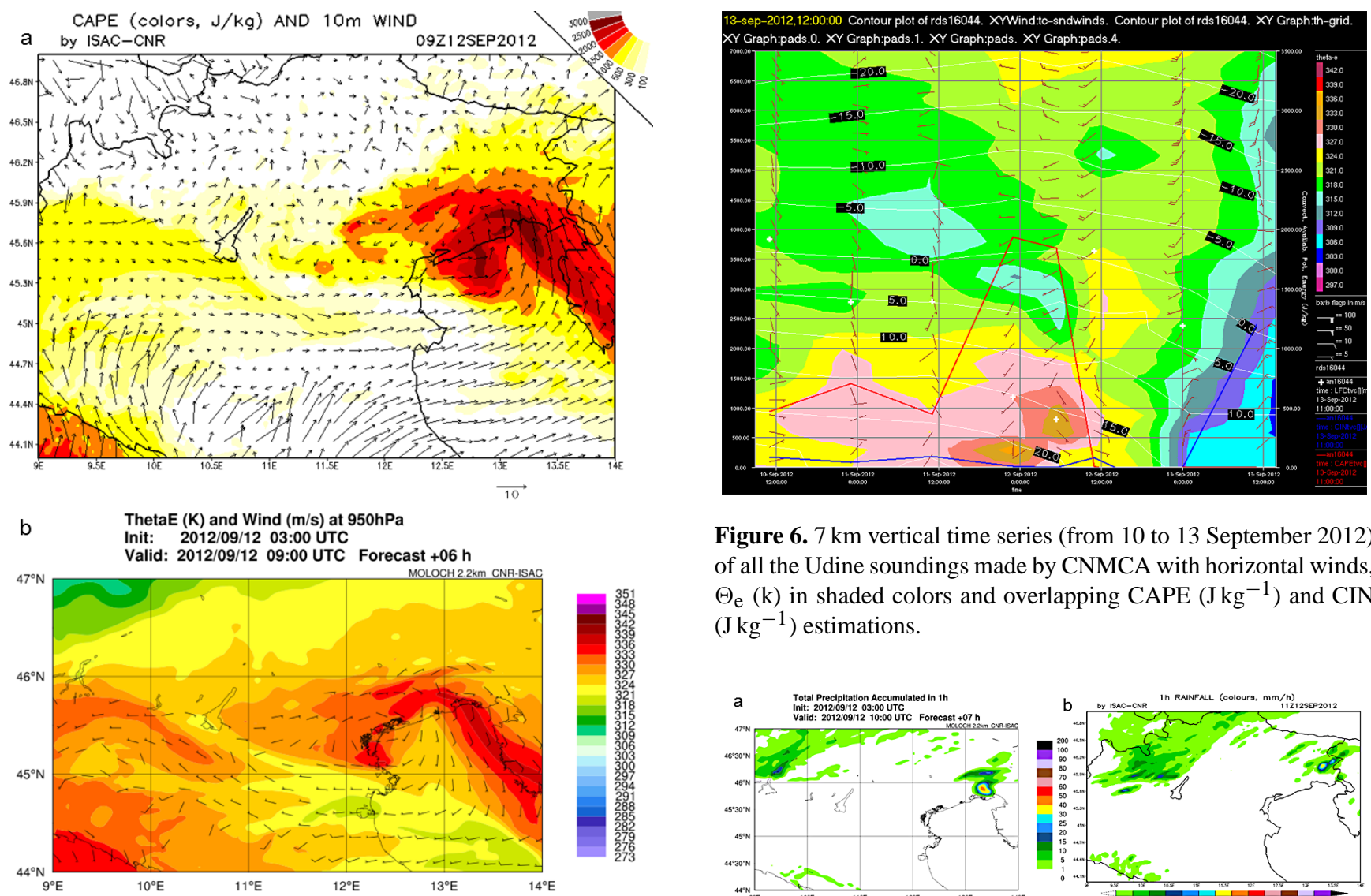

Figure 6. $7 \mathrm{~km}$ vertical time series (from 10 to 13 September 2012) of all the Udine soundings made by CNMCA with horizontal winds, $\Theta_{\mathrm{e}}(\mathrm{k})$ in shaded colors and overlapping CAPE $\left(\mathrm{J} \mathrm{kg}^{-1}\right)$ and CIN $\left(\mathrm{J} \mathrm{kg}^{-1}\right)$ estimations.
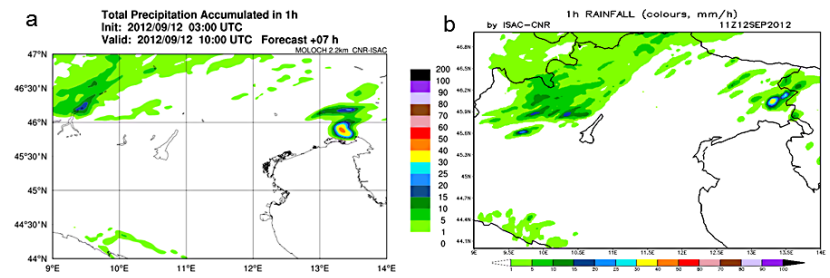

Figure 5. (a) CAPE $\left(\mathrm{J} \mathrm{kg}^{-1}\right)$ and horizontal wind at $10 \mathrm{~m}$ by the WRF-ISAC run driven by GFS forecasts starting at 12:00 UTC, 11 September; (b) equivalent potential temperature $(\mathrm{K})$ and wind at $950 \mathrm{hPa}$ by MOLOCH-ISAC at the $2.3 \mathrm{~km}$ run driven by GFS forecasts starting at 00:00 UTC, 12 September.

$\left(45.73^{\circ} \mathrm{N}, 13.49^{\circ} \mathrm{E}\right)$ radar detected two small areas of precipitation exceeding $150 \mathrm{~mm}$ in $24 \mathrm{~h}$ (not shown). The daily accumulated precipitation reached up to $106 \mathrm{~mm}$ at Palazzolo $\left(45.81^{\circ} \mathrm{N}, 13.05^{\circ} \mathrm{E}\right.$, Fig. $\left.3 \mathrm{~b}\right)$, with a detected hourly maximum of 52 and $13 \mathrm{~mm}$ in only $5 \mathrm{~min}$. In the following, the hailstorm that hit Latisana $\left(45.78^{\circ} \mathrm{N}, 12.99^{\circ} \mathrm{E}\right)$ at about 09:00 UTC will be analyzed in more detail.

In the morning of 12 September 2012, two thunderstorms developed in the area, hereafter called the "Northern Storm" (affecting the Rauscedo area at $46.04^{\circ} \mathrm{N}, 12.83^{\circ} \mathrm{E}$ ) and the "Southern Storm" (affecting the area west of Latisana). The Northern Storm was active by 06:30 UTC (08:30 local time) over the western part of FVG and moved southeastward; the Southern Storm started later (08:00 UTC) on the northern Adriatic coast of Veneto and moved inland toward the northeast. The southeasterly low-level wind feeding moisture toward the orographic barrier of the Carnic Pre-Alps is probably one of the factors leading to the development of the Northern Storm (Kerkmann et al., 2012). The vertical maximum intensity (VMI) of the radar in Fossalon di

Figure 7. Hourly accumulated precipitation on 12 September: (a): at 10:00 UTC, forecast by MOLOCH-ISAC; (b): at 11:00 UTC, forecast by WRF-ISAC.

Grado at 08:20 UTC and the surface station measurements at 08:25 UTC overlapped with the cloud-to-ground lightning (source CESI-SIRF) clearly show (Fig. 4a) the moist flow. The high values of equivalent potential temperature $\left(\Theta_{\mathrm{e}}\right)$ along the coast (Lignano, $45.70^{\circ} \mathrm{N}, 13.14^{\circ} \mathrm{E}$ ) and inland (Palazzolo), respectively 341 and $342 \mathrm{~K}$, support the hypothesis of a localized high- $\Theta_{\mathrm{e}}$ flux feeding the storms (Figs. 4 and 5a, b). A sudden reinforcement of the Southern Storm as shown by the radar (Fig. $4 \mathrm{~b}$ and c, 08:40 and 09:00 UTC, respectively) suggests the convergence of the southeasterly low-level wind with the downdraft produced by the Northern Storm (Fig. 4) as the mechanism for its reinforcement. This led to the formation of a storm with supercell features. Highresolution forecasts (WRF-ISAC and MOLOCH-ISAC) further support this hypothesis, showing a weak convergence between the downdraft produced by the cells and the southeasterly flow (not shown) at the time of the reinforcement of the Southern Storm. The supercell features are further confirmed by the radar image (Fig. 4c): the maximum reflectivity values (above $60 \mathrm{dBZ}$ ) are located at about $5 \mathrm{~km}$ a.m.s.l., with a very low cloud base (about $500 \mathrm{~m}$ high) and a top above $13 \mathrm{~km}$. Moreover, a meso-cyclone signature in the Doppler 


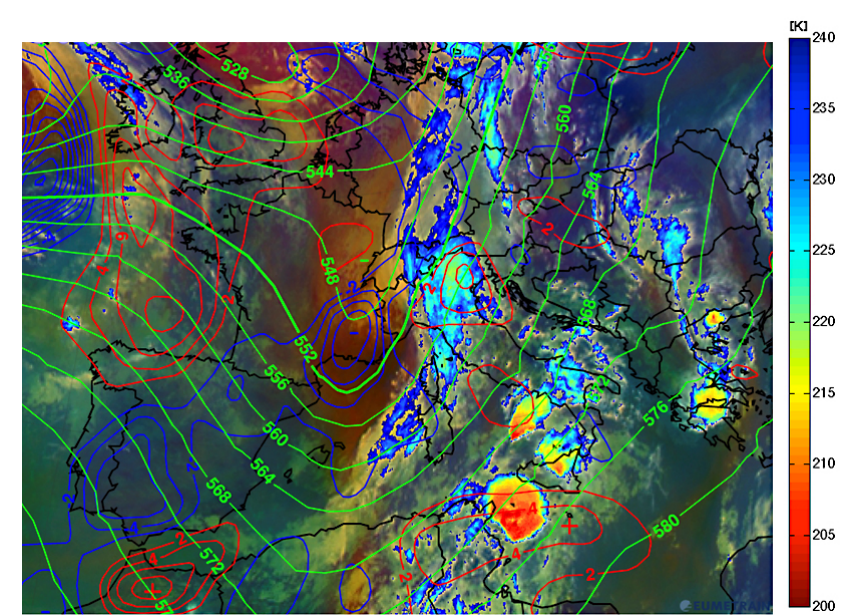

Figure 8. As in Fig. 2, but at 12:00 UTC, 15 October 2012. Source: http://www.eumetrain.org.

field (not shown) was detected. Finally, at 09:00 UTC strong hail was reported on the A14 highway near Latisana. At the same time a "convergence line" developed in the northern Adriatic as most of the operational high-resolution models had predicted (not shown). Afterward, the "Southern" cell moved eastward, dissipating nearby Trieste at 11:00 UTC.

The Udine-Campoformido $\left(46.03^{\circ} \mathrm{N}, 13.18^{\circ} \mathrm{E}\right)$ extrasoundings at 06:00 and 18:00 UTC allowed for profiles available every $6 \mathrm{~h}$. During the morning, very high values of potential instability with a $\Theta_{\mathrm{e}}$ maximum above $330 \mathrm{~K}$ between 500 and $1000 \mathrm{~m}$ in altitude (Fig. 6) were detected. A strong rotation of the low-level winds between the 06:00 UTC and the 18:00 UTC was also found, confirming a suitable environment for strong convective activity. The 06:00 UTC Udine sounding exhibited a lifted index of only $-0.7^{\circ} \mathrm{C}$, but the difference in temperature between the most unstable parcel $\left(\Theta_{\mathrm{e}}=336 \mathrm{~K}\right)$ lifted pseudo-adiabatically at $500 \mathrm{hPa}$ and the environmental air (DT500) was as low as $-5.0^{\circ} \mathrm{C}$. CAPE was almost $1680 \mathrm{~J} \mathrm{~kg}^{-1}$ and the precipitable water (PWE) was $34 \mathrm{~mm}$. These values of potential instability indices were very high for this time of year in FVG (mid-September).

Finally, the ATR42 flew over the northern Adriatic Sea, detecting the low-level southerly flow by midday, that is after the supercell ended. LIDAR measurements (not shown) documented a well-developed PBL (up to $2 \mathrm{~km}$ ) over the Adriatic Sea characterized by high values of the water vapor mixing ratio.

\subsubsection{Peculiarities and model simulations}

Short-range forecasts reproduced fairly well the large-scale and mesoscale features responsible for the event. In fact, all the investigated high-resolution operational models capture the convergence among the low-level jet (LLJ) close to the east coast of the northern Adriatic, the southwesterly flow across the Apennines (similar to alpine Foehn), and the east- northeasterly barrier flow just inshore the FVG coast (Fig. 5a, b). This convergence was responsible for the convective triggering. A strong gradient of $\Theta_{\mathrm{e}}$ over the Adriatic was produced by the warm and moist air associated with the LLJ and the dry SW airflow. The northern part of the LLJ reached the coasts of FVG, producing a tongue of high values of $\Theta_{\mathrm{e}}$ and CAPE (Fig. 5a, b). Although the mesoscale environment is correctly reproduced, the exact location and timing of cells depended weakly on both the model and the initial condition. Indeed, small differences had a strong impact on the simulation of the convective cells that crossed the NEI area during the entire day. Focusing on the morning event, no model simulation was able to reproduce the evolution of both storms correctly. For example, the $2.3 \mathrm{~km}$ MOLOCHISAC run (initialized through the GFS forecasts starting at 00:00 UTC, 12 September) reproduced the southern cell fairly well (Fig. 7a) but missed the northern one, while the WRF run (initial conditions at 12:00 UTC, 11 September) captured only the northern cell (Fig. 7b).

In summary, the local observations associated with radar measurements and model output allow for depiction of the local dynamics and thermodynamics structure of this event. Both the observed and modeled surface flow suggest warm and moist advection as one of the mechanisms feeding the storm. Moreover, observations confirm that the convergence of the southeasterly low-level wind with the downdraft produced by the Northern Storm is the mechanism for developing deep convection.

\subsection{IOP 13 - CI}

IOP13 occurred on 15-16 October 2012 and was characterized by an NAO index of approximately zero (0.13 and 0.6 , respectively, during 15 and 16 October). Similarly to IOP2, weak westerlies allowed for the transition of heavy rain storms over the Mediterranean area. All of the three Italian target areas were involved. An overview of the event over the $\mathrm{CI}$ area is presented in the following sections.

\subsubsection{Synoptic situation}

This IOP was selected as a typical situation of frontal precipitation affecting central and northeastern Italy. The precipitating events were associated with a wide upper-level trough extending from northern Europe to Spain (Fig. 8) in the early morning of 15 October 2012. A cold front moved eastward, advecting low-level moist air towards Corsica and Italy. The main convective activity was located in the warm air ahead of the front, in the narrow cold frontal rainband and behind, under the upper cold low. During the morning of that day a secondary V-shaped trough started to form over France and moved eastward. A strong PV anomaly (the reddish area in Fig. 8) associated with the deep trough and the warm temperature advection at $700 \mathrm{hPa}$ allowed the development of 


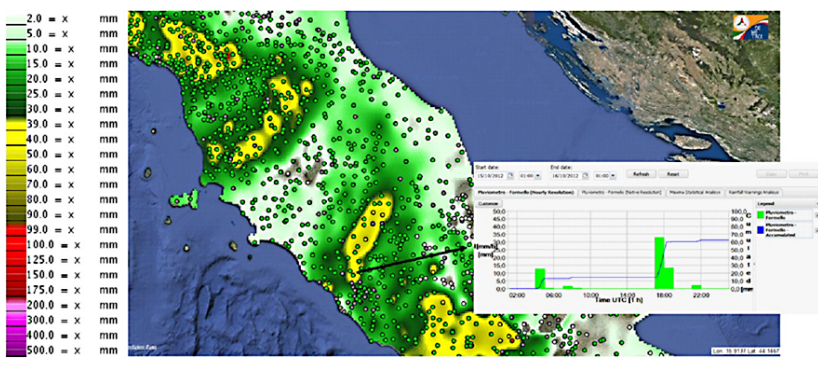

Figure 9. Daily accumulated rainfall recorded by rain gauges (green dots on the map) on 15 October 2012; the inset shows the hourly accumulated precipitation for the station of Formello (north of Rome) - courtesy of the DPC (DEWETRA system).

several MCSs in the central and southern Tyrrhenian Sea (Fig. 8).

In the following hours the upper level trough deepened, moving eastward, and by 18:00 UTC of 15 October a cyclone had developed over the Gulf of Genoa (not shown). The associated frontal system moved rapidly toward the Italian peninsula, causing moist air advection over the Tyrrhenian Sea and consequent deep convection on the Tyrrhenian coast, east of Rome. In the evening a cut-off low developed over northern Italy, moving eastward and crossing the northeastern part of the Italian peninsula by the early morning of 16 October.

\subsubsection{Observations}

During this IOP all the operational instruments and the ones purposely deployed over the CI site were operational, with the exception of the Monte Midia weather radar, which had been out of order since 13 October. Figure 9 shows the $24 \mathrm{~h}$ accumulated precipitation on 15 October recorded by the Italian rain gauge networks: a maximum of $60 \mathrm{~mm} / 24 \mathrm{~h}$ was reached. The inset in Fig. 9 shows the hourly precipitation recorded by one of the rain gauges located north of Rome (Formello, $12^{\circ} 23^{\prime} 55.34^{\prime \prime} \mathrm{E}, 42^{\circ} 04^{\prime} 41.40^{\prime \prime} \mathrm{N}$ ). It clearly shows that most of the precipitation occurred in the late afternoon (from 17:00 to 19:00 UTC), with a remarkable maximum of rainfall rate of $35 \mathrm{~mm} \mathrm{~h}^{-1}$ at 18:00 UTC, whereas light precipitation was recorded during the night and in the morning. The spatial distribution and the evolution of precipitation can be inferred from the radar reflectivity pattern (Fig. 10). Most of the precipitation occurred on the western slope of the Apennines. Indeed, the NASA Parsivel disdrometers purposely installed at L'Aquila (on the eastern slope) and Pescara (on the east coast of CI) recorded only 9.8 and $5.0 \mathrm{~mm}$, respectively, on that day. Conversely, at "La Sapienza" University of Rome, the NASA 2-D video disdrometer recorded a total amount of $25 \mathrm{~mm}$. An hourly cumulated rainfall of $20 \mathrm{~mm}$ was recorded between 17:40 and 18:40 LST, but $114 \mathrm{~mm} \mathrm{~h}^{-1}$ being the highest rain rate estimated in $1 \mathrm{~min}$. Such measurements are consistent with the

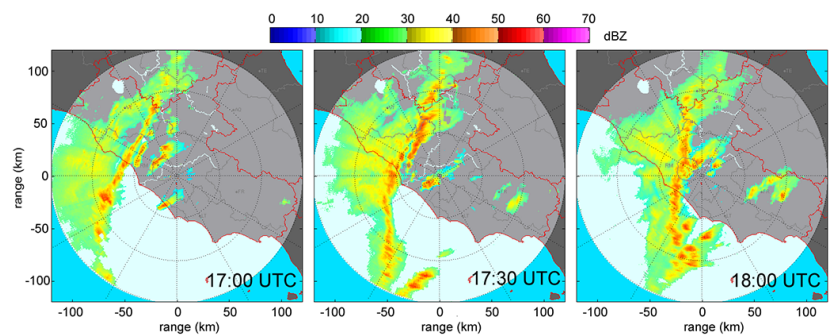

Figure 10. Reflectivity images at different times (17:00, 17:30 and 18:00 UTC) collected by Polar 55C radar in Rome during 15 October 2012 (elevation $1.6^{\circ}$ ).

ones of the operational rain gauges available in downtown Rome.

In addition to the operational soundings available from the Global Telecomunication System (GTS), dedicated extra soundings were launched by the HyMeX Italian team as listed in Table 5. Two instrumented aircrafts (ATR42 and F20) were used to provide evidence of the moist southwesterly flow and the vertical cloud structure. The ATR42 flew on 15 October over the Tyrrhenian Sea; the earlier flight (takeoff at 05:00 UTC from Montpellier to Bastia) crossed the cold front; the later one (take-off at 08:00 UTC from Bastia to Sicily and back) crossed the southwesterly flow. The return flight took place from Bastia to Montpellier at the end of the morning. The flight was successful except for returning early (before reaching Palermo) because of the presence of cumulonimbus clouds over Sicily.

The F20 flight was dedicated to documenting the cloud properties of the precipitation systems, exploiting the joint coverage of X- and C-band radars in central Italy, and measurements collected by the RASTA (Radar Aéroporté et Sol de Télédétection des propriétés nuageuses; Protat et al., 2009) $94 \mathrm{GHz}$ Doppler radar onboard the F20 aircraft. The main objectives of these joint observations were (i) to intercompare the capabilities of dual polarized radars at $\mathrm{C}$ - and $\mathrm{X}$-bands having different specifications (i.e., different beam widths, peak powers, central wavelengths, scanning modes) and (ii) to compare the radar-derived microphysical retrievals with a ground-based network of disdrometers in terms of particle size distributions and precipitation rates. Preliminary results (Marzano et al., 2013) show that path attenuation correction and clutter removal are critical steps in radar data processing, especially at X-band, whereas good agreements have been found between radar products and disdrometer data for the particle concentration and mean diameter estimation, especially for stratiform rainfall.

The Polar 55C CNR radar was available during this IOP to provide, from the Rome site, both conventional volumes scanning made of sweeps at different elevations and RHI mode that scans with an increasing elevation angle at a fixed azimuth direction, along both the directions of the HyMeX instrumented sites and along the F20 route. The reflectivity 


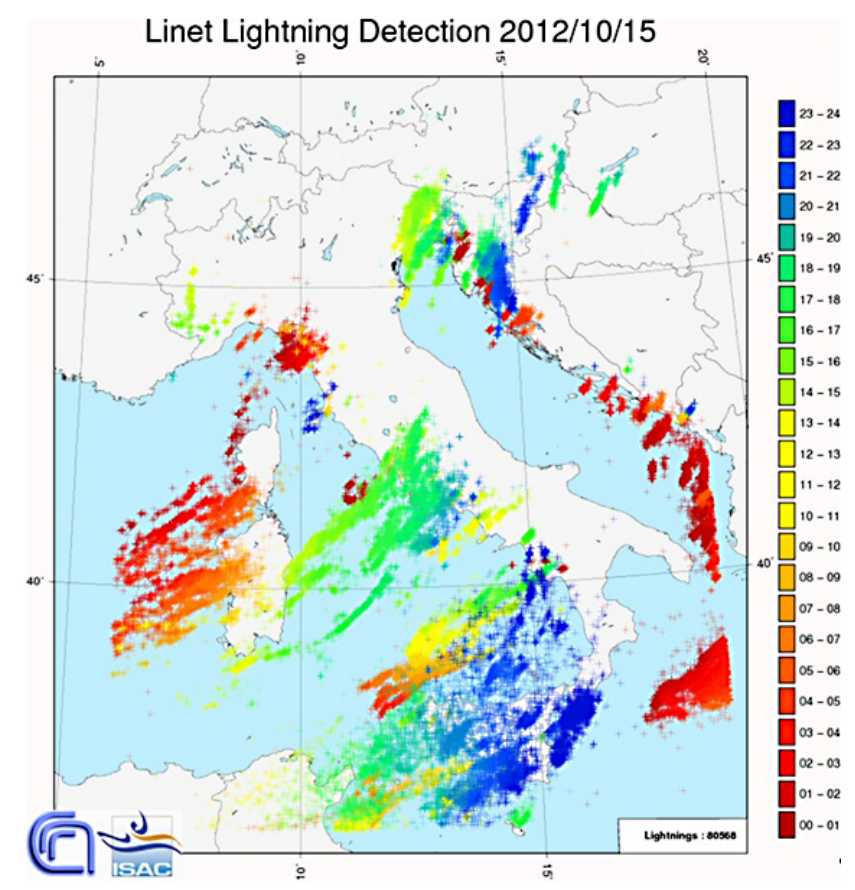

Figure 11. LINET lightning activity measured on 15 October 2012. The map shows the intra-cloud and cloud-to-ground strikes registered in $24 \mathrm{~h}$. Different colors are associated with different hours.

maps were collected by Polar 55C on 15 October at an elevation angle of $1.6^{\circ}$. This angle allows both to avoid the influence on radar beam propagation of obstacles close to the radar and at the same time to keep the radar beam at a low height. For a correct interpretation of the radar maps, it should be noted that a sector between the azimuth angles of 120 and 150 degrees is almost blocked by the Colli Albani hills. The reflectivity maps collected at 04:00, 07:00 and 10:00 UTC (not shown) show weak precipitation characterized by sparse convective systems. At 04:00 UTC convective cells developed over the Tyrrhenian Sea, and moved along the northeasterly direction. Later on this system was replaced by a second one of smaller extent. The third system, characterized by more scattered cells, originated southward with respect to the previous ones. No lightning activity was detected at these time steps, either over the sea or around Rome (Fig. 11). In the afternoon, a well-organized squall line, aligned NE-SW, developed and moved southeastward, as shown by the radar (Fig. 10) and the lightning images (Fig. 11). The most intense part of the system moved very rapidly across Rome. The peak intensity of lightning activity in Rome occurred between 18:00 and 19:00 UTC, and was associated with the most intense precipitation.

At 17:57 UTC Polar 55C operated in RHI mode along the direction of $293^{\circ}$ azimuth. Figure 12 shows reflectivity and differential reflectivity (respectively a and b in Fig. 12), both corrected for rain attenuation effects, and reveals the vertical extent (up to $10 \mathrm{~km}$ ) of the convective cells (note that the ap- parent decrease in the height with distance from radar is an effect of both attenuation and reduction of the minimum detectable signal with distance). The presence of a convection core at $4 \mathrm{~km}$ (Fig. 12b) is confirmed by large, positive values of differential reflectivity co-located with high reflectivity values that are typically associated with heavy rain with (or formed from) melting graupel or small hail (Meischner et al., 1991). The trailing part of the convective systems exhibits a quite thick and not well-defined bright band signature (Fig. 12c, d).

The F20 flight started as soon as the most intense convection began to decrease, supported by a correct forecasting of the convective activity well before its occurrence. The F20 aircraft took off at 18:20 UTC from Montpellier, followed a flight plan over $\mathrm{CI}$ and reached the rainfall area over the Italian peninsula at 19:00 UTC (Fig. 13). To acquire as much valuable information as possible it performed two loops around the Rome-Pescara transect (Fig. 13); no dropsondes were launched. During the flight along the northern leg convective precipitation was observed close to $\mathrm{CI}$, behind the cold front. Between 19:20 and 20:30 UTC the most interesting legs were performed; during the Rome-Pescara route, the height of the flight was around $10 \mathrm{~km}$, just above the top of the cloud, confirming the height observed by the Polar 55C RHI scans. On the way back, both of the height and speed (see the white track in the top panel of Fig. 13) of the aircraft decreased, allowing in-cloud flights. The $94 \mathrm{GHz}$ reflectivity recorded by the RASTA radar provides a clear signature of the melting layer. Figure 12 shows an RHI collected by Polar 55C during the F20 flight. Both sensors detected a stratiform structure of precipitation. Differential reflectivity shows an increase around $6 \mathrm{~km}$ height and $10 \mathrm{~km}$ distance from the radar, reaching positive values and indicating the formation of oblate ice particles.

\subsubsection{Peculiarities and model simulations}

For this event both deterministic and ensemble forecasts were analyzed. This diversity of products eased the operational forecaster's work. The fairly good agreement among the models in forecasting moderate precipitation over the western side of CI supported the decision for the flight planned on the afternoon of 15 October 2012. As will be pointed out in the following, the models reproduced quite well the rain patterns from the Tyrrhenian coast to the western side of the Apennines (Figs. 14, 15 and 17).

The WRF-CETEMPS simulation initialized on 14 October 2012 at 12:00 UTC shows the onset of the low-level southwesterly jet after midnight. The flux strengthened during the morning, reaching a maximum of wet and warm advection in the late afternoon. The $\Theta_{\mathrm{e}}$ map shows values over $330 \mathrm{~K}$ intruding into the middle Tyrrhenian coast (Fig. 14a); the convergence between the southwesterly and the westerly flows allowed for the triggering and development of a convective line. The radar detected between 17:00 and 18:00 UTC 

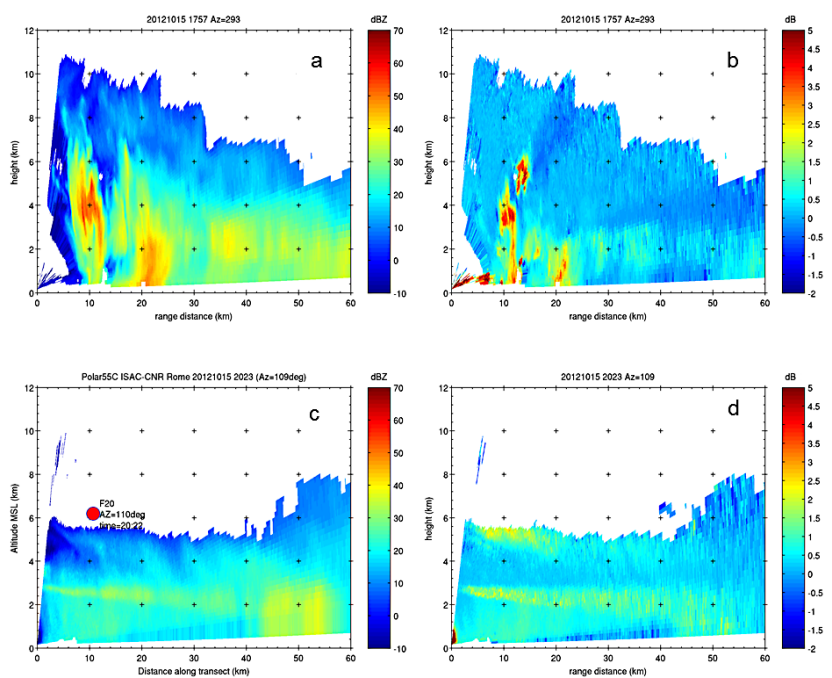

Figure 12. Polar 55C radar in RHI mode on 15 October 2012 (azimuth $293^{\circ}$ ) at 17:57 UTC: (a) sections of reflectivity; (b) differential reflectivity. Polar 55C pointing to a direction along the Falcon 20 route on 15 October 2012 at 20:25 UTC: (c) reflectivity; the solid red circle indicates the aircraft position; (d) differential reflectivity.
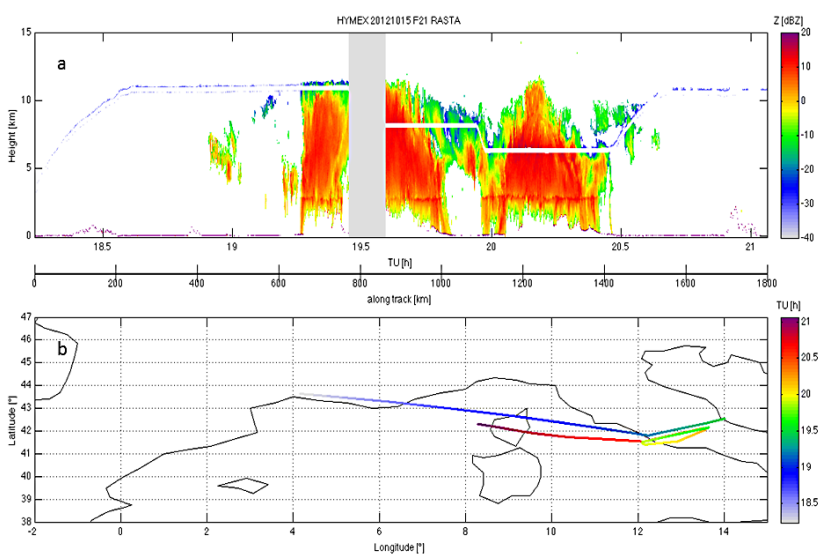

Figure 13. Falcon 20 flight on 15 October 2012 (18:00 UTC to 21:00 UTC): (a) reflectivity; (b) flight track. Courtesy of Julien Delanoe (LATMOS/IPSL/UVSQ, France).

(Fig. 10) a convective squall line over the western side of the CI target area. WRF-CETEMPS correctly reproduces the timing and the multi-cellular character of this structure, as shown by the simulated radar reflectivity (Fig. 14b). The comparison between the $24 \mathrm{~h}$ precipitation measured by the rain gauges (Fig. 9) and the model (Fig. 15a) displayed very good agreement in terms of both maximum value (approximately $60 \mathrm{~mm} / 24 \mathrm{~h}$ ) and location (the northeastern side of the Lazio region). Similarly, MOLOCH-ISPRA (using the same initialization as WRF-CETEMPS) reproduced the growth of the Tyrrhenian low-level jet during the morning and the development of the two squall lines during the afternoon, but displayed some differences in the details of the rainfall fields.

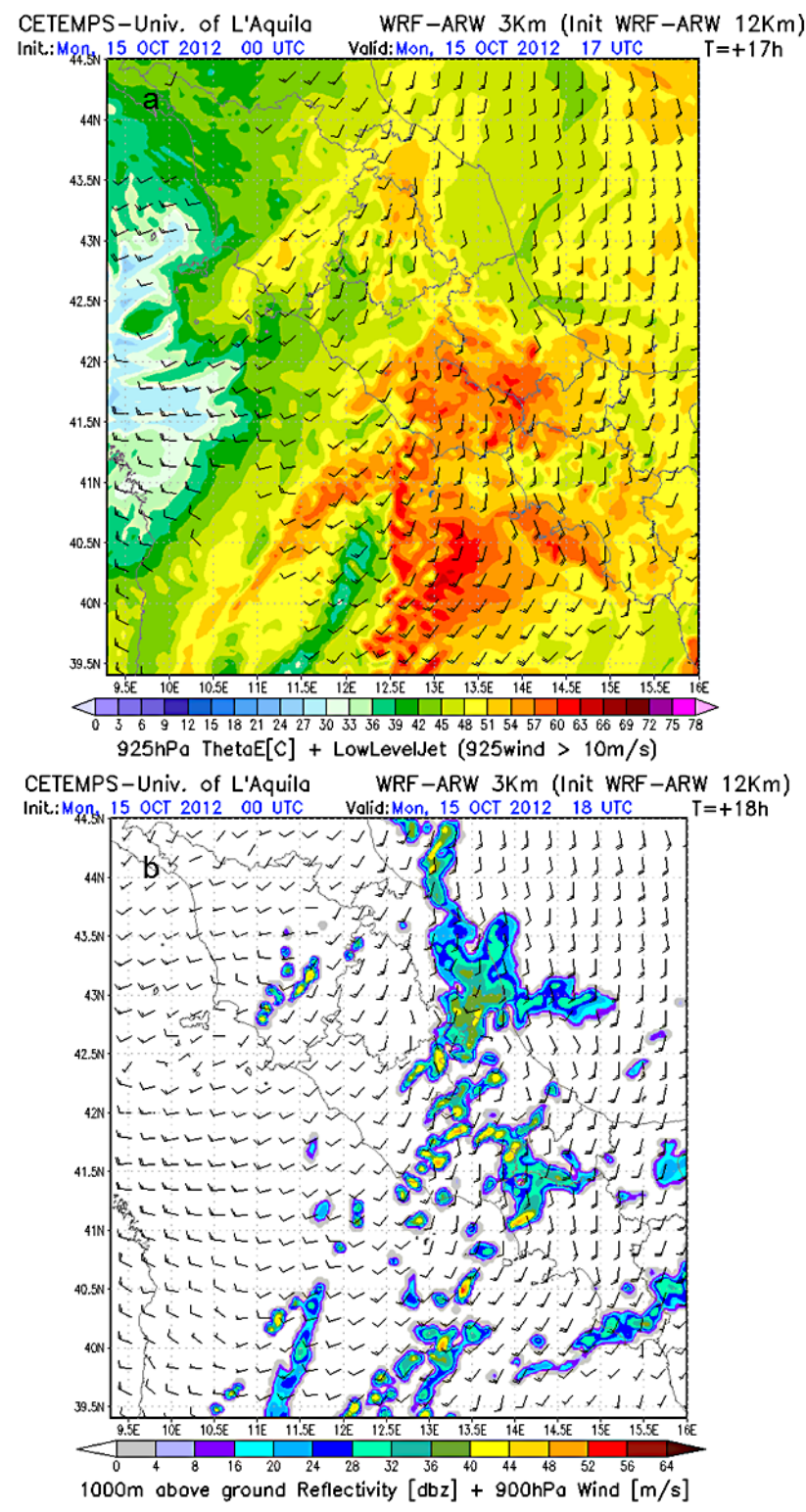

Figure 14. (a) WRF equivalent potential temperature $\left({ }^{\circ} \mathrm{C}\right)$ and lowlevel jet at $925 \mathrm{hPa}$; (b) WRF reflectivity at $850 \mathrm{hPa}(\mathrm{dbz})$ and wind at $925 \mathrm{hPa}$ (WRF-CETEMPS initialized by ECMWF at 12:00 UTC, 14 October 2012).

As a result, the $24 \mathrm{~h}$ precipitation forecast (Fig. 15b) provided a good forecast for the northern squall line (Fig. 9), but differences in the forecast between MOLOCH-ISPRA and WRFCETEMPS were instead larger over other areas: the former model seems to have provided a better forecast over northern Campania $\left(41.5^{\circ} \mathrm{N}, 13-14^{\circ} \mathrm{E}\right.$, Fig. $\left.15 \mathrm{~b}\right)$, while the latter model performed better over southern Tuscany $\left(43-44^{\circ} \mathrm{N}\right.$, $10.5-11^{\circ}$ E, Fig. $\left.15 a\right)$.

A correct space-time forecast of multiple squall lines that grow into the warm sector of a Mediterranean cyclone during its passage on the Tyrrhenian Sea may crucially depend 

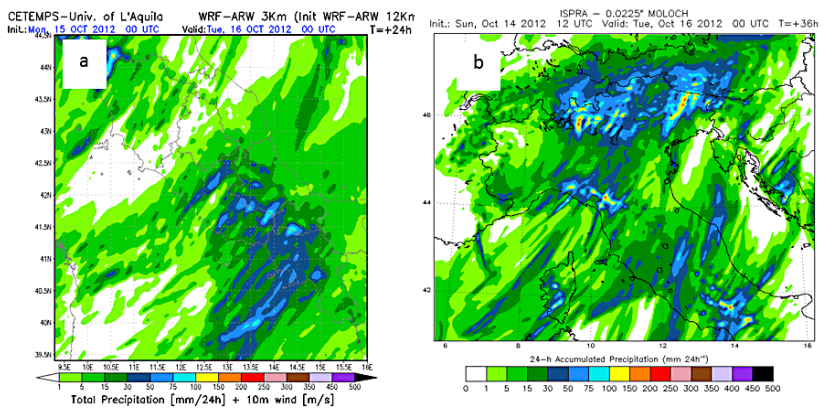

Figure 15. Daily precipitation $(\mathrm{mm} / 24 \mathrm{~h})$ valid at 00:00 UTC on 16 October 2012 simulated by (a) WRF-CETEMPS and (b) MOLOCH-ISPRA, both initialized by ECMWF at 12:00 UTC, 14 October.
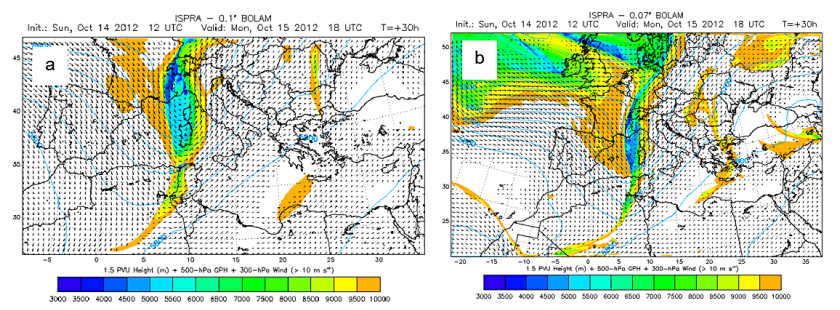

Figure 16. $500 \mathrm{hPa} \mathrm{GPH}$ (blue contour lines), $300 \mathrm{hPa}$ wind $\left(>10 \mathrm{~m} \mathrm{~s}^{-1}\right.$ ) and 1.5 PVU isosurface (color shaded area) for the forecast initialized at 12:00 UTC of 14 October 2012 and valid at 18:00 UTC of 15 October 2012 for (a): $0.1^{\circ}$ BOLAM-ISPRA and (b) $0.07^{\circ}$ BOLAM-ISPRA.

on the ability of the NWP model to reproduce the fine structure of the cyclone. This clearly appears when comparing the synoptic forecasts provided by the 0.07 BOLAM-ISPRA (which drives the MOLOCH-ISPRA) with the corresponding ones provided by the $0.1^{\circ}$ BOLAM-ISPRA (belonging to the low-resolution ISPRA forecasting chain). In particular, at 18:00 UTC on 15 October, the $0.07^{\circ}$ BOLAM (Fig. 16, right panel) shows a more accurate forecast (in shape and in position) of the PV anomaly, evidenced by the reddish region in the SEVIRI AirMass RGB image (Fig. 8), than the $0.1^{\circ}$ BOLAM (Fig. 16, left panel). The correct forecast of the PV anomaly contributed to the increased skill of the rainfall forecast. Indeed, the double convergence line over the Tyrrhenian Sea is found only for the $0.07^{\circ}$ BOLAM forecast (not shown).

As for the probabilistic prediction of this event, COSMOLEPS provided an early indication of the possible occurrence of an HPE over the CI area. At the $72 \mathrm{~h}$ forecast range, the possibility of a heavy precipitation scenario was shown by some ensemble members (e.g., members 3, 7 and 8), with a good prediction in terms of the amount and, to a lesser extent, location. This was confirmed by the probability maps of precipitation exceeding 10 and $50 \mathrm{~mm}$ in $24 \mathrm{~h}$ (Fig. 17a, $\mathrm{b}$ respectively), which indicated $\mathrm{CI}$ as an area possibly af-
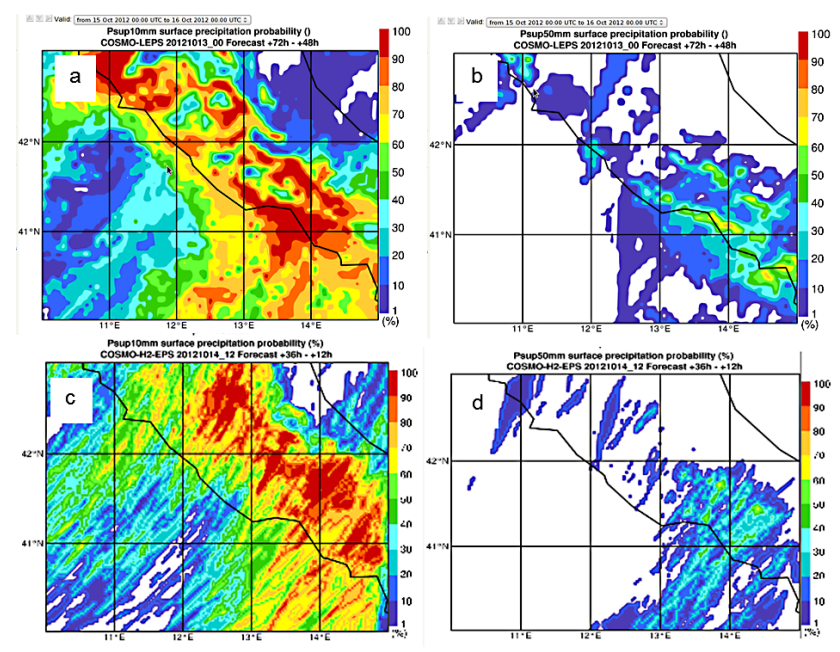

Figure 17. COSMO-LEPS (emission time: 00:00 UTC of 13 October 2012 , fcst $+48-72 \mathrm{~h}$ ) probability maps of $24 \mathrm{~h}$ precipitation exceeding (a) $10 \mathrm{~mm}$ and (b) $50 \mathrm{~mm}$. COSMO-H2-EPS (emission time: 12:00 UTC of 14 October 2012, fcst $+12-36 \mathrm{~h}$ ) probability maps of $24 \mathrm{~h}$ precipitation exceeding (c) $10 \mathrm{~mm}$ and (d) $50 \mathrm{~mm}$.

fected by moderate-to-intense precipitation with probability peaks of $70 \%$ at the higher threshold. At shorter time ranges, the high-resolution information conveyed by COSMO-H2EPS is shown in Fig. 17c and d. The $24 \mathrm{~h}$ predicted precipitation by the 10 ensemble members clearly showed a better localized area possibly affected by heavy rain: some ensemble members predicted the occurrence of precipitation greater than $50 \mathrm{~mm}$ in the region $41-42^{\circ} \mathrm{N}, 13-14^{\circ} \mathrm{E}$. The probability maps for $24 \mathrm{~h}$ precipitation greater than 10 and $50 \mathrm{~mm}$ (Fig. $17 \mathrm{c}$ and d, respectively) indicated that the area most likely affected by the weather events was located more inland rather than near the cost, confirming the information provided by the deterministic systems (Fig. 15).

Further investigation using data from IOP13 is necessary to evaluate why two deterministic model chains sharing the same ECMWF initialization provided an overall good forecast but with some differences. It is worthwhile investigating whether these differences are a consequence either of the different models used (MOLOCH vs. WRF), the differences in the parent model design $\left(0.07^{\circ}\right.$ BOLAM vs. $\left.12 \mathrm{~km} \mathrm{WRF}\right)$, or a combination of both; this will be the aim of a future study.

Finally, it is worth pointing out that the availability of both in situ and airborne measurements allowed for characterization of the precipitation:

- both in situ and airborne radar measurements (Polar 55C and RASTA) support the hypothesis of stratiform precipitation and oblate ice particles.

- radar and disdrometer showed good agreement in particle concentration and mean diameter estimation, especially for stratiform rain. 


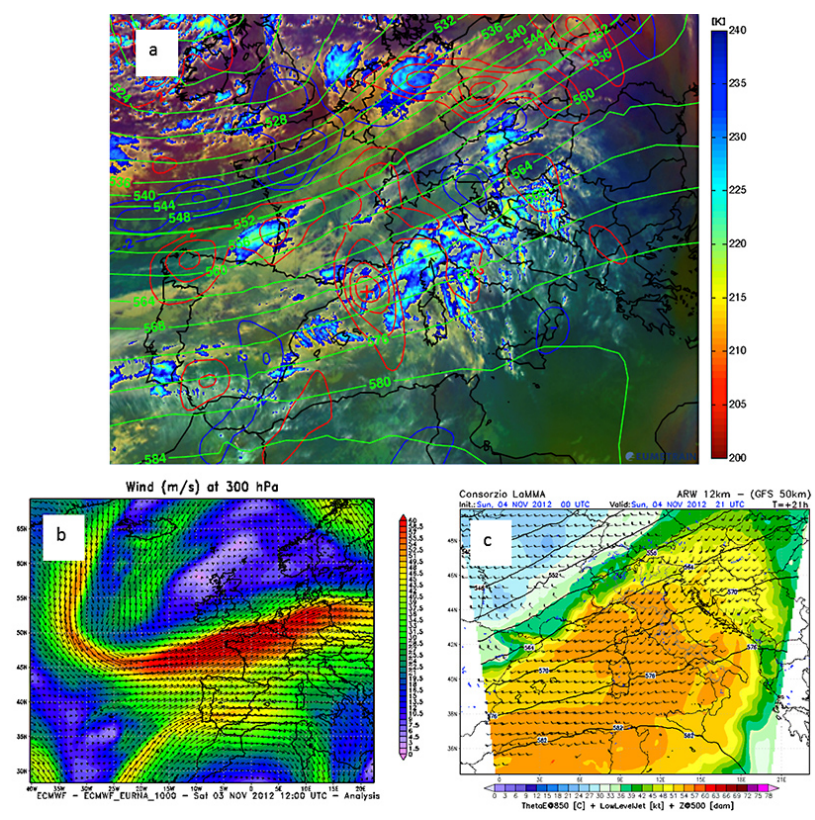

Figure 18. (a) As in Fig. 2 but at 12:00 UTC, 3 November 2012. Source: http://www.eumetrain.org. (b) Wind speed at $300 \mathrm{hPa}$ : ECMWF analysis, 4 November 2012 at 12:00 UTC; (c) equivalent potential temperature and low-level jet at $850 \mathrm{hPa}$, geopotential height at $500 \mathrm{hPa}$ from WRF-ARW LaMMA.

- model simulations show the role of the convergence line developed in the Tyrrhenian Sea in triggering the line of deep convection as recorded by the radar.

\subsection{IOP 19 - LT}

IOP19 was dedicated to HPE over LT-NEI on 3-5 November, which induced local flash-flooding. The event was characterized by a well-defined negative NAO index, -2.7 during the first day and -3.3 during the second one, remaining negative or zero until the end of the year. The large negative values of NAO definitely weakened the westerlies and allowed for a strong baroclinic wave to form, extending from Great Britain to northern Africa. This produced a southwesterly flow in the western Mediterranean region during the whole IOP19.

\subsubsection{Synoptic situation}

During 3 November 2012, an upper-level low extending over the North Atlantic Ocean began to move southward, turning its axis counterclockwise approaching western Europe. A strong polar upper-level jet (more than $70 \mathrm{~m} \mathrm{~s}^{-1}$ ) associated with the trough began to flow over the western Mediterranean, connecting to the subtropical one (Fig. 18a, b). The Mediterranean Sea was affected by strong southwesterly flows at the middle and low levels $\left(20 \mathrm{~m} \mathrm{~s}^{-1}\right.$ at $700 \mathrm{hPa}$ and $15 \mathrm{~m} \mathrm{~s}^{-1}$ at $850 \mathrm{hPa}$ ), and a warm conveyor belt ahead of the cold front advected very warm subtropical air (values of $\Theta_{\mathrm{e}}$ at $850 \mathrm{hPa}$ of more than $323 \mathrm{~K}$, not shown). On the evening of

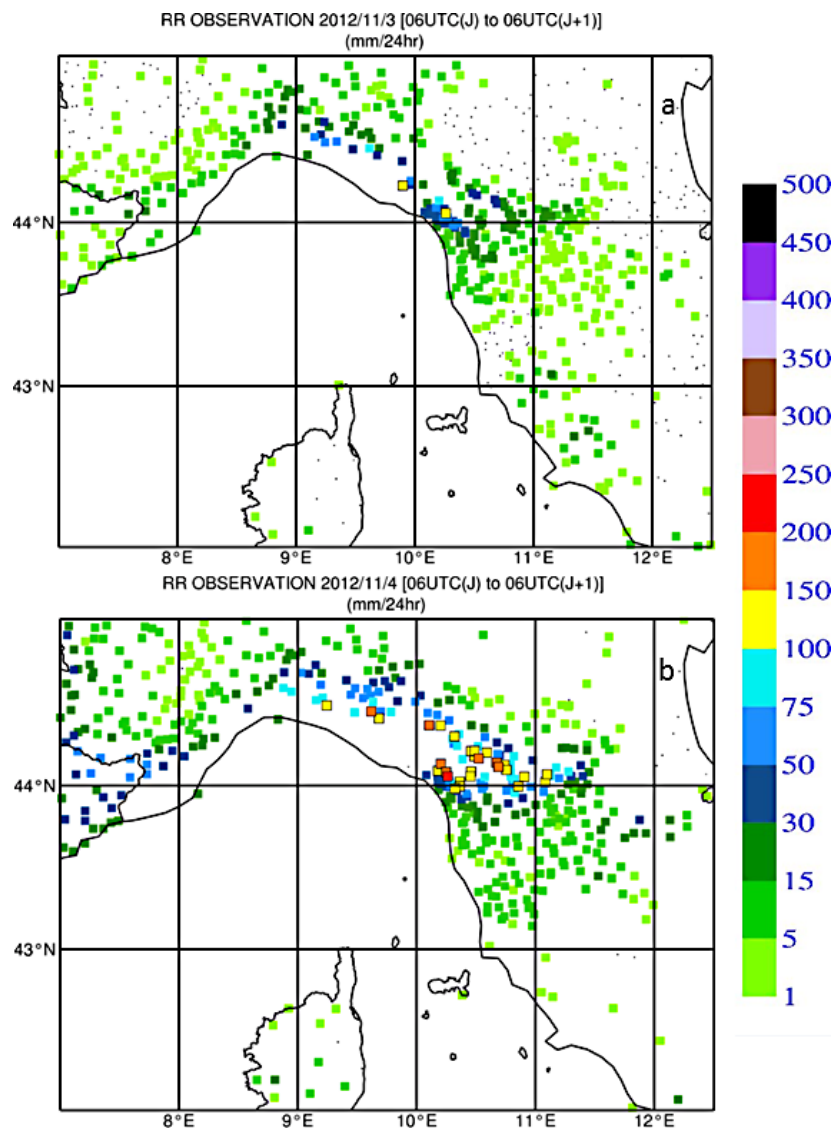

Figure 19. Observed $24 \mathrm{~h}$ accumulated precipitation ending at 06:00 UTC on (a) 3 November 2012; (b) 4 November 2012 (source: sop.hymex.org).

4 November 2012, a surface cyclone developed over the Gulf of Lion, enhancing a strong southerly flow over the Tyrrhenian and Ligurian seas. By 21:00 UTC, WRF-ARW LaMMA shows the entrance of a southwesterly low-level jet associated with a strong increase in $\Theta_{\mathrm{e}}$ (Fig. 18c). The PBL balloon confirms the model flow by showing a strong southwesterly wind at $20 \mathrm{~m} \mathrm{~s}^{-1}$ at approximately $925 \mathrm{hPa}$ (Fig. 22c, d) when approaching the Gulf of Genoa by 20:00 UTC on 4 November.

The synoptic situation remained unchanged until the morning of 5 November, because of the blocking associated with a high-pressure area over Russia. Then, the weakening of the ridge allowed the cold frontal system to move eastward across Italy.

\subsubsection{Observations}

During IOP19 heavy precipitation occurred over both LT and NEI. On 3 November maxima of precipitation were recorded mostly on the Ligurian side of the target area. At Novegigola station $\left(44.22^{\circ} \mathrm{N}, 9.89^{\circ} \mathrm{E}\right.$, and $382 \mathrm{~m}$ a.m.s.l $)$ precipitation reached $85 \mathrm{~mm} / 24 \mathrm{~h}$, with an hourly precipitation of 

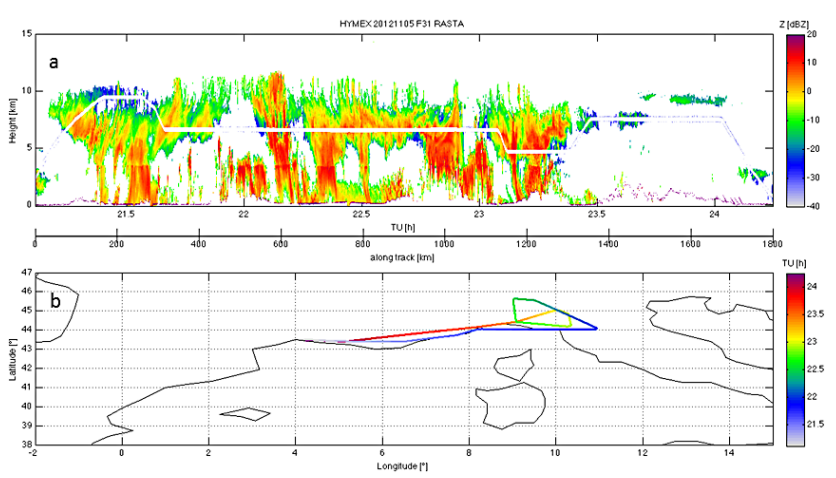

Figure 20. Falcon 20 flight on 4 November 2012 (21:00 UTC to 23:50 UTC): (a) reflectivity; (b) flight track. Courtesy of Julien Delanoe (LATMOS/IPSL/UVSQ, France).

$15 \mathrm{~mm} \mathrm{~h}^{-1}$ between 16:00 and 17:00 UTC (Fig. 19a). During the following day, the southwesterly flow moved southward, shifting the maxima of precipitation towards Tuscany, especially over the Apuan Alps and the northern Apennines range. During this day, the Campagrina station $\left(44.05^{\circ} \mathrm{N}\right.$, $10.26^{\circ} \mathrm{E}$, and $832 \mathrm{ma}$ a.m.s.l) recorded $226 \mathrm{~mm} / 24 \mathrm{~h}$, with a maximum hourly precipitation of $33 \mathrm{~mm} \mathrm{~h}^{-1}$, between 23:00 and 00:00 UTC (Fig. 19b). Most of the rain was recorded between 18:00 UTC on 3 November and 04:00 UTC on 5 November, reaching $317 \mathrm{~mm} / 3$ days at Campagrina. The maximum hourly precipitation was $39 \mathrm{~mm} \mathrm{~h}^{-1}$ between 02:00 and 03:00 UTC on 5 November at Lago Scaffaiolo $\left(44.12^{\circ} \mathrm{N}, 10.81^{\circ} \mathrm{E}\right.$, and $1811 \mathrm{~m}$ a.m.s.l), just after the entrance of a strong low-level jet advecting warm air toward this area. The precipitation was mainly orographic, with an average hourly rate of approximately $6-10 \mathrm{~mm}$ and peaks of $30-40 \mathrm{~mm}$. No deep convection was observed, as the lack of lightning suggests.

In the following hours the system moved inland, producing precipitation over the northern Apennines at Lago Scaffaiolo, where two maxima were recorded: $124 \mathrm{~mm} / 24 \mathrm{~h}$ and $39 \mathrm{~mm} \mathrm{~h}^{-1}$ between 02:00 and 03:00 UTC, 5 November 2012 (not shown).

During IOP19 additional observations were made: the aircrafts (ATR42 and F20) flew in the upstream part of the flow, deploying dropsondes, and two planetary boundary layer balloons from the Balearic Islands flew towards the Gulf of Genoa (Table 5).

The F20 took off from Montpellier to fly over the LT area from 21:00 UTC, 4 November (flight number 3, Fig. 20b), measuring reflectivity with the RASTA Doppler radar (Fig. 20a) along the flight track. High reflectivity values were recorded between 22:00 and 23:15 UTC, when the F20 flew over the Gulf of Genoa and the Apennines range; high values were detected over the whole atmospheric column up to $8-10 \mathrm{~km}$, with maxima at approximately $5 \mathrm{~km}$ and over the mountains (Fig. 20a) supporting the hypothesis of a lack of deep convection.

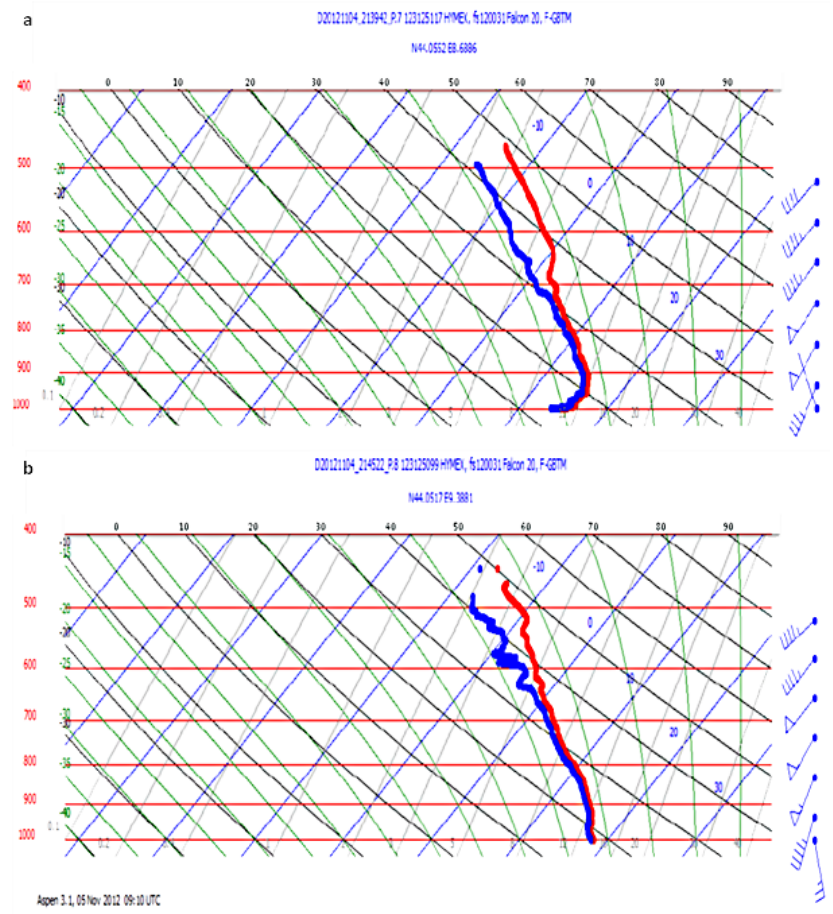

Figure 21. Vertical profile from the two dropsondes deployed by the Falcon flight over the Gulf of Genoa at (a) DS1 $\left(44.055^{\circ} \mathrm{N}\right.$, $\left.8.689^{\circ} \mathrm{E}\right)$ at $21: 40 \mathrm{UTC}$, and (b) DS2 $\left(44.052^{\circ} \mathrm{N}, 9.388^{\circ} \mathrm{E}\right)$ at 21:45 UTC. Courtesy of Julien Delanoe (LATMOS/IPSL/UVSQ, France).

Also, two dropsondes were deployed in the Gulf of Genoa at DS1 $\left(44.055^{\circ} \mathrm{N}, 8.689^{\circ} \mathrm{E}\right)$ and DS2 $\left(44.052^{\circ} \mathrm{N}, 9.388^{\circ} \mathrm{E}\right)$ at 21:40 UTC and 21:45 UTC, respectively, documenting a nearly saturated profile up to $700 \mathrm{hPa}$. DS1 showed a sharp low-level inversion, below $900 \mathrm{hPa}$ (Fig. 21a). This is produced by a northerly low-level flow locally advecting cooler air from the Po Valley, as the lowest level wind observation suggests (Fig. 21a, DS1). On the contrary, intense southern (southwesterly aloft) wind was recorded at DS2. This wind pattern, northerly out-flow (density current) on the western side of the Ligurian coast and southerly advection in the eastern part, is often observed in this area, in correspondence with heavy precipitation events. Among the mesoscale models, the WRF-ARW LaMMA clearly showed cold air and easterly low-level wind in the Po Valley producing an outflow on the eastern side of the Liguria region (not shown). Several model-based case studies of past events occurring in this area (IOP8 during MAP 19-22 October 1999, Cinque Terre and Genoa Floods, 25 October and 4 November 2011, respectively) produced this local wind structure (Rotunno and Ferretti, 2003; Buzzi et al., 2012; Ferretti et al., 2012), which had never been confirmed until now because of the lack of observations. Finally, wind velocity at DS1 increased with height with a maximum of $30 \mathrm{~m} \mathrm{~s}^{-1}$ over $500 \mathrm{hPa}$, whereas at DS2 


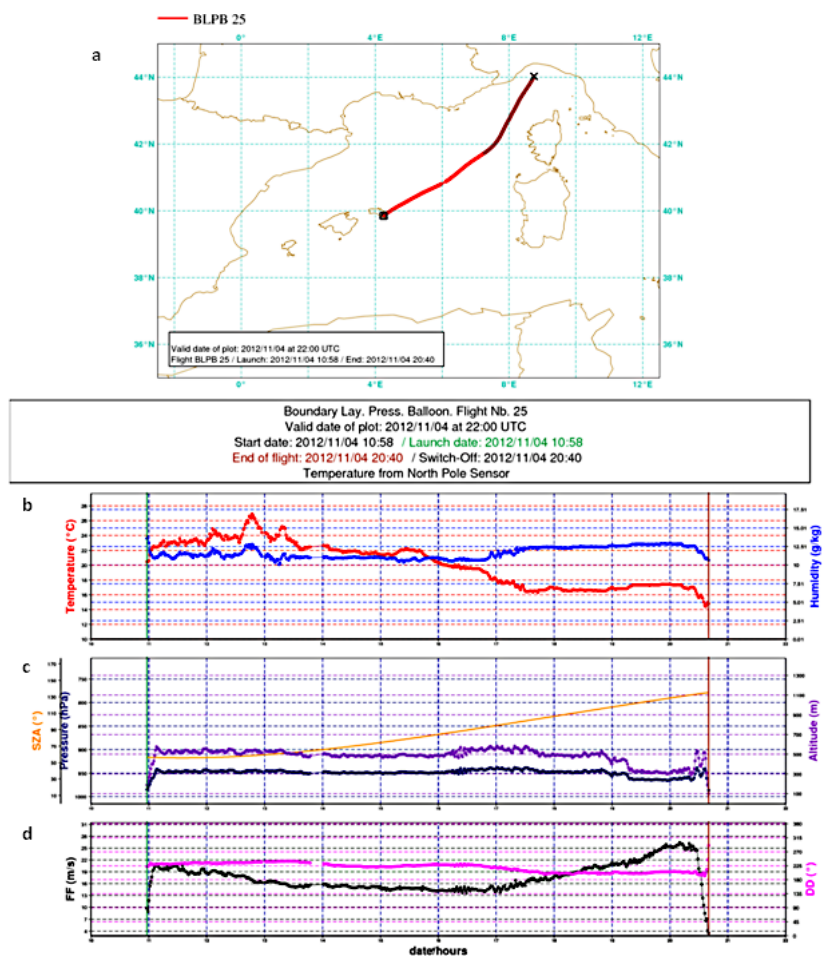

Figure 22. (a) PBL balloon (\#25) track. Measurement time series along the balloon track launched on 4 November 2012 at 10:58 UTC from the Balearic Islands ending at 20:40 UTC in the Genoa Gulf; (b) temperature (red line) and relative humidity (blue line); (c) pressure (dark blue) and altitude (purple line); (d) wind intensity (black line) and direction (pink line). Courtesy of Alex Doerenbecher (CNRM-France).

(Fig. 21b) the wind velocity reached a maximum $\left(25 \mathrm{~m} \mathrm{~s}^{-1}\right)$ at $700-800 \mathrm{hPa}$.

Two PBL balloons were launched from Minorca on 4 November at 11:00 UTC and at 14:30 UTC, respectively. Both reached the Gulf of Genoa (Fig. 22), measuring temperature, relative humidity, wind and pressure. Along the balloon track a temperature drop starting at 16:00 UTC associated with a wind intensity increase and a local depression was clearly recorded (Fig. 22a, b, c). At this time the balloon was out of the Gulf of Genoa and precipitation had already started, as the observations suggest.

\subsubsection{Peculiarities and model simulations}

IOP19 was characterized by heavy precipitation occurring on the northwestern edge of Tuscany. This represents a typical event in this area, generally well forecast days in advance by operational models that are able to describe the main orographic forcing properly.

The heavy precipitation occurring in this area is mostly produced by southwesterly warm and moist air advection producing an unstable environment, as the increasing values of CAPE and the low-level wind forecast by WRF-ARW
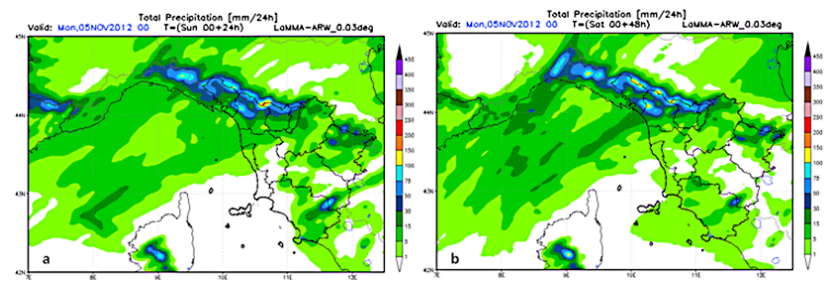

Figure 23. WRF-ARW by LaMMA: $24 \mathrm{~h}$ accumulated precipitation for 4 November 2012. (a) $+24 \mathrm{~h}$ forecast; (b) $+48 \mathrm{~h}$ forecast.

LaMMA during 4 November (Fig. 18c) suggest. The topography also plays a critical role either in lifting humid air above the Apennines (reaching $1800 \mathrm{~m}$ in less than $20-30 \mathrm{~km}$ from the coast) or in forcing the low-level wind direction, possibly developing a local area of convergence. The correct forecast of the low-level convergence is crucial, because it determines the location where the maxima of precipitation occur, leading to flash floods. The local low-level flow convergence may also occur because of low-level cold air in the Po Valley, producing a very stable stratified boundary layer (ground thermal inversion), which produces an intense local drainage flow or gap flow from the valley, restraining the inflow on the eastern edge of the Liguria region or the northwestern edge of Tuscany and resulting in nearly oppositeproducing local convergence.

The previous characteristics are generally well reproduced if high-resolution models are used; e.g., the increase in the horizontal (and consequently also the vertical) resolution allows for a better representation of the topography, however the reduction in grid spacing below a value of approximately $6 \mathrm{~km}$ requires the non-hydrostatic assumption. Both these allow for a better reproduction of convective cells as they are explicitly resolved.

The observed precipitation showed two distinct maxima (Fig. 19) over the two parallel mountain ridges (being the Apuan Alps on the west and close to shore, and the Apennines ridge on the east). Maxima values of precipitation reached approximately $220 \mathrm{~mm}$ over the Apuan and $130 \mathrm{~mm}$ over the Apennines. Most of the models correctly simulated the precipitation structure with the two maxima over the two mountain ridges, but most of them produced more precipitation over the Apennines than on the Apuan: WRF-ARW LaMMA overestimated the precipitation over the Apennines producing $150-200 \mathrm{~mm}$ and slightly underestimated the rain on the Apuan producing 100-150 mm (Fig. 23a). This result implies that WRF-ARW overestimated the orographic forcing associated with the highest mountain ridge (the Apennines) which produces an underestimation of the Apuan maxima of precipitation.

Besides different physics, characteristics, and employed initial/boundary conditions (ECMWF or GFS; see Sect. 2.2 for model configuration details), most of the Italian operational models produced similar positions and amounts of 

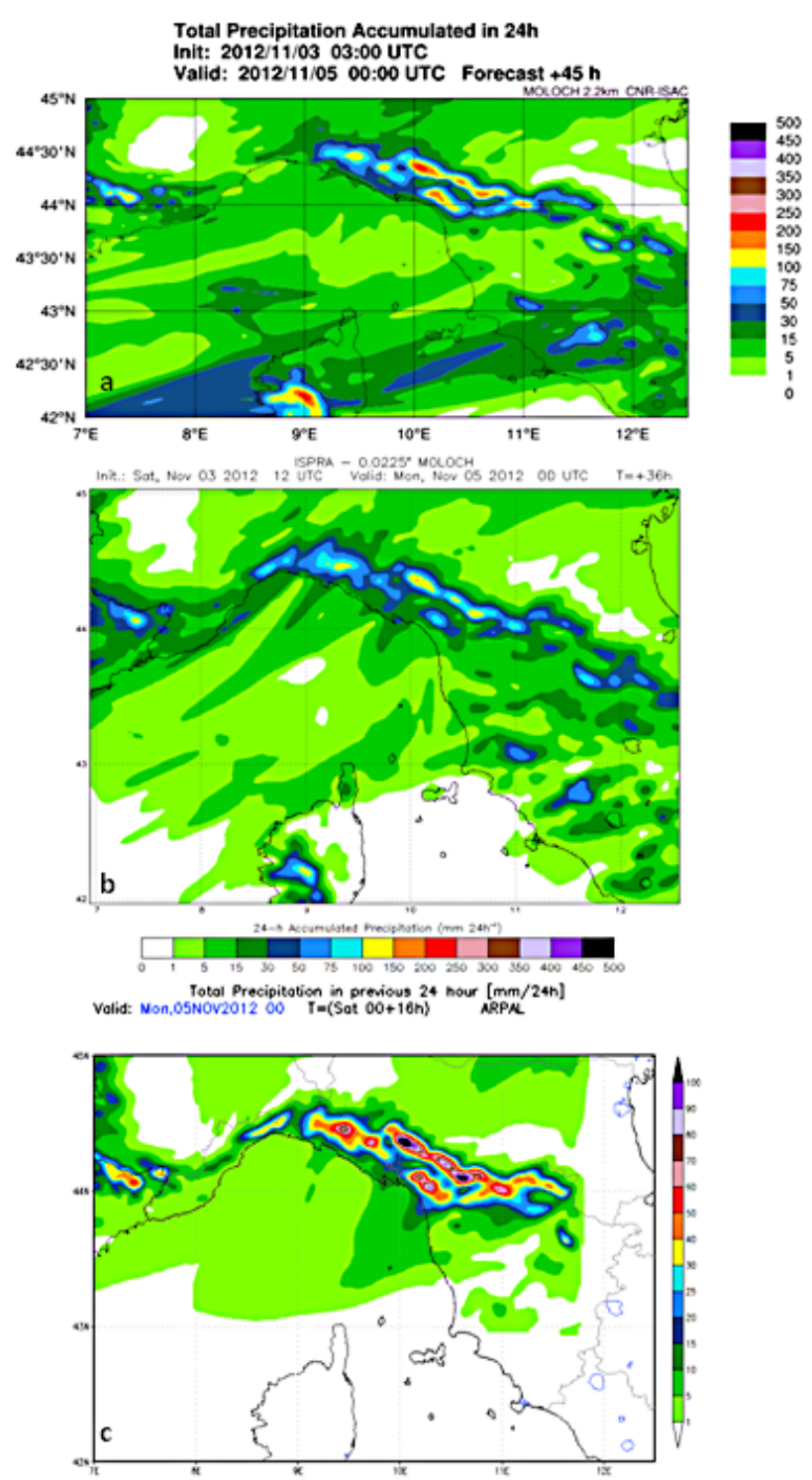

Figure 24. $24 \mathrm{~h}$ accumulated precipitation at 00:00 UTC, 5 November 2012, forecast by different operational chains using MOLOCH: (a) CNR-ISAC at $2.3 \mathrm{~km}$ starting at 03:00 UTC on 3 November; (b) ISPRA at $2.5 \mathrm{~km}$ starting at 12:00 UTC on 3 November; (c) ARPAL at $2.3 \mathrm{~km}$, starting at 00:00 UTC on 3 November 2012 .

the precipitation maxima, as will be discussed in the next section. Moreover, the $+24 \mathrm{~h}$ and the $+48 \mathrm{~h}$ WRF-ARW LaMMA forecasts (Fig. 23a, b) showed very similar patterns, suggesting very high forecast reliability.

Apart from an incorrect distribution of the maxima, the weather forecast during IOP19 enables us to assess that heavy orographic precipitation in this area is quite well forecast by numerical models. As far as precipitation distribution and amounts are concerned, differences between models and configurations exist, even though a direct comparison might also be influenced by initial conditions. The most interesting object of study for this IOP is the exact location of the max- ima of the precipitation, a subject that needs further modeling investigation.

It is worth pointing out that the availability of in situ measurements as well as the ones taken during the flight allowed for the detailed analysis of the precipitation structure. The combined use of model and measurements indicated that this event was characterized by

- orographic precipitation with no deep cells, as the RASTA and the lack of lightning suggest,

- rainfall that was fed by advection of warm and moist air, as detected by dropsondes at $925 \mathrm{hPa}$ and by the PBL balloon,

- a convergence of inflow and outflow, respectively, in the western and eastern parts of the Liguria region, as detected by the dropsondes at the lower levels.

\subsection{Operational chains during IOP19}

With the aim of investigating the usefulness of the operational chains during the campaign further and understanding the previously analyzed feature of IOP19 better, a gross inter-comparison between all the Italian operational models is carried out for this IOP only. Because of the different configurations (domain, resolution, initialization, etc.) of the operational forecasts, a rigorous inter-comparison between the models cannot be performed. However, the following exercise will allow the inference of a sort of spread of the precipitation forecasts. The $24 \mathrm{~h}$ accumulated precipitation ending at 00:00 UTC of 5 November is shown for all the available models (Figs. 24, 25, 26). Figure 24 shows the $24 \mathrm{~h}$ accumulated precipitation for the operational chains using MOLOCH. All of them caught the two observed maxima (Fig. 19) and the pattern of the precipitation distribution. The values of the two maxima differ among the MOLOCHs, varying from approximately $250 \mathrm{~mm} / 24 \mathrm{~h}$ down to $100 \mathrm{~mm} / 24 \mathrm{~h}$, but as for the previously analyzed results of WRF-ARW LaMMA, the maximum is produced in the Apennines, suggesting again too strong an orographic forcing. As far as the operational chains using WRF-ARW (Fig. 25) are concerned, the precipitation pattern was again well reproduced in terms of both intensity and distribution. Finally, regarding the ensemble forecast from COSMO (Fig. 26), the position where intense precipitation is expected agrees with the observations, thus reinforcing the deterministic model results. As for the other low-resolution models, the maxima are underestimated (not shown). The previous results suggest a good ability of WRF-ARW to reproduce the observed rainfall, for this case. Because of the similar configuration used for the three WRF chains, this result may be related to both microphysics and PBL parameterizations, which are both different from those of the other models. One can also speculate about the different vertical level distribution in the PBL as one of the reasons for the different rainfall 

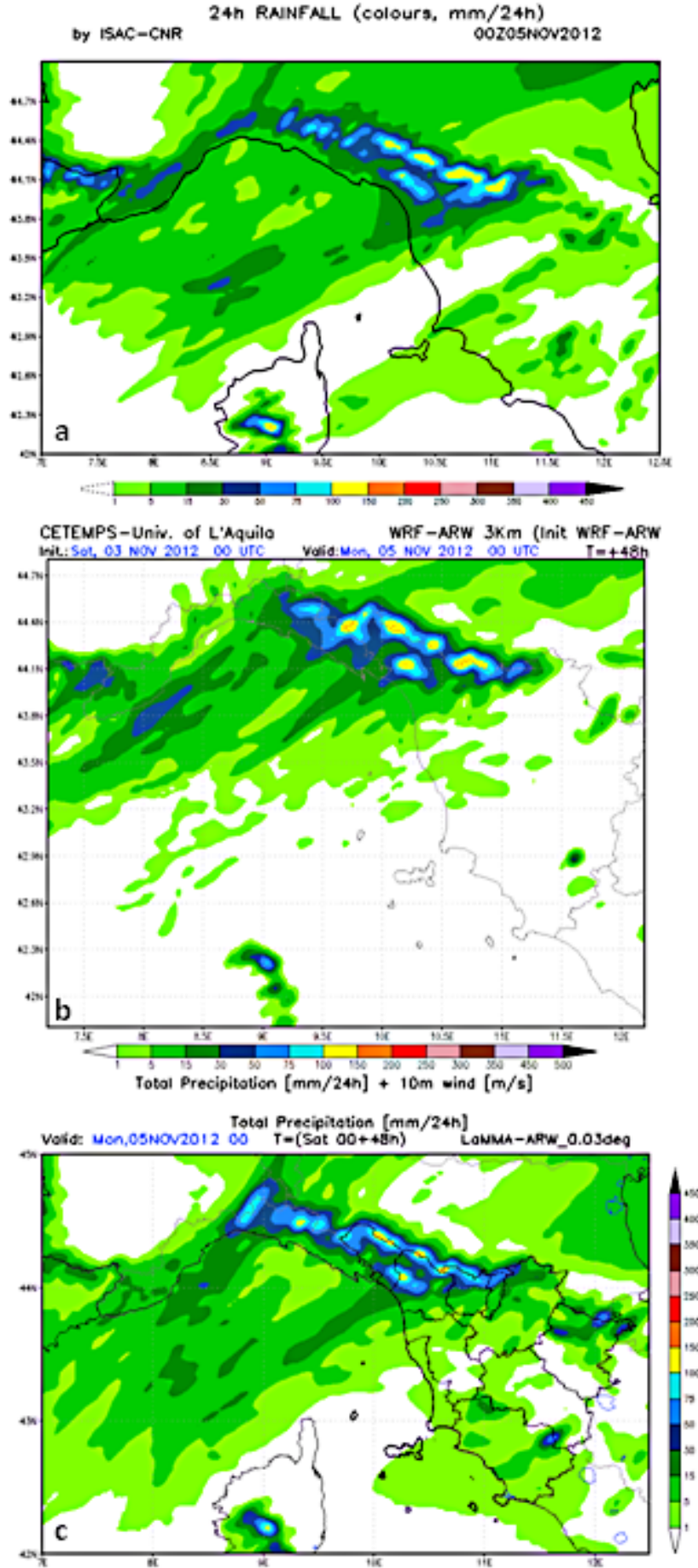

Figure 25. $24 \mathrm{~h}$ accumulated precipitation forecast by different operational chains using WRF-ARW: (a) CNR-ISAC at $3 \mathrm{~km}$ starting at 00:00 UTC, 3 November; (b) CETEMPS at $3 \mathrm{~km}$ starting at 00:00 UTC, 3 November; (c) LAMMA at $3 \mathrm{~km}$ starting at 00:00 UTC, 3 November.
Psup10mm surface precipitation probability (\%) COSMO-H2-EPS 20121103_12 Forecast $+36 \mathrm{~h}-+12 \mathrm{~h}$

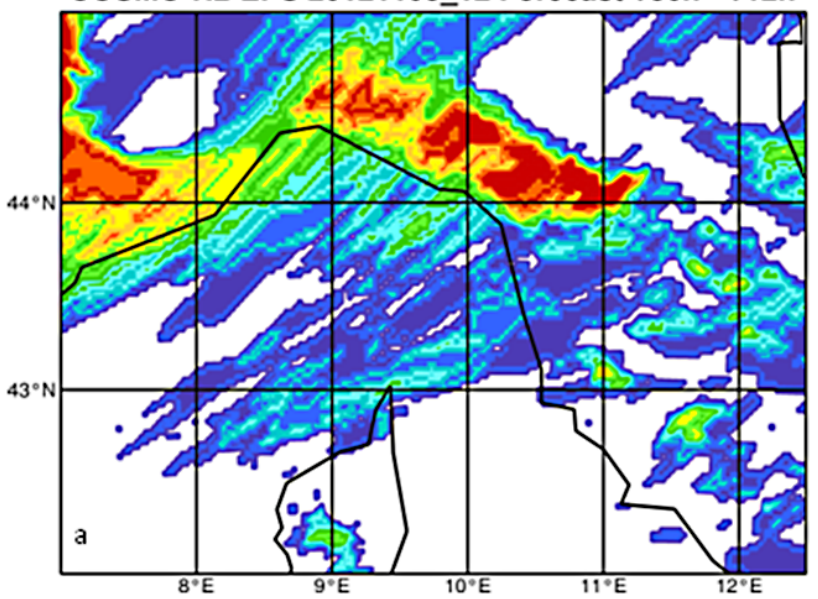

Psup50mm surface precipitation probability (\%) COSMO-H2-EPS 2012110312 Forecast $+36 h-+12 h$

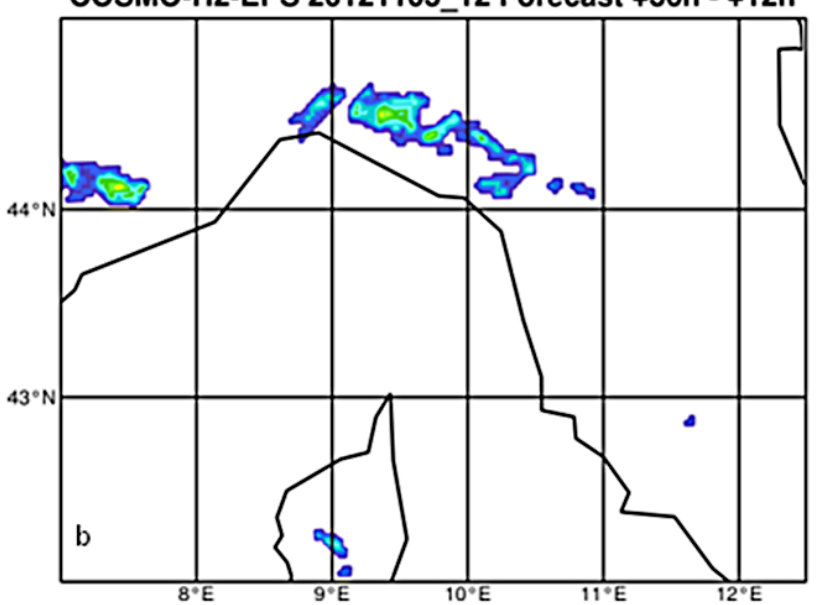

Figure 26. COSMO-H2-EPS ensemble forecasts: (a) precipitation probability above $10 \mathrm{~mm}$; (b) precipitation probability above $50 \mathrm{~mm}$.

forecasts between WRF-ARW and MOLOCH, but further investigations are required to assess these points. However, this is not a general result because the best-performing model is not always the same for the IOPs analyzed in this paper. This result stresses the importance of using high-resolution multi-model multi-analysis forecasting systems in order to compensate for the limitations of predictability due to model error.

The previous results are obtained using different models and different configurations (a sort of multi-model multianalysis ensemble), suggesting that the precipitation forecast for IOP19 was highly predictable both for the amount and location. However, different results from similar chains indicate that model settings may maintain remarkable variability in the precipitation forecasts. In any case, this gross inter-comparison indicates the usefulness of using different 
model chains for weather forecasting. A deeper analysis of the model results should be performed to understand model behaviors, but it is beyond the aim of this paper and left to future work.

\section{Summary and perspective}

In this paper an overview of the IOPs that occurred in Italy during the SOP1 HyMeX campaign (5 September-6 November 2012) is presented. During the campaign three hydro-meteorological sites were identified in Italy: LiguriaTuscany (LT), northeastern Italy (NEI) and central Italy (CI). Operational instruments ran at all the Italian hydrometeorological sites, and over CI research instruments were also activated during selected IOPs. All events were characterized by a trough (smooth or deep) entering the Mediterranean region from the northwest and deepening while crossing the Mediterranean Sea. All of them produced localized heavy precipitation and often were properly forecast by the available operational models. Three of them were used to test the reliability not only of the weather forecast but of the entire meteo-hydro and hydro-meteo-marine chains. The hydrological response in terms of floods was investigated during IOP4: the operational hydro-meteo (CHyM) chain allowed for forecasting of the risk of flood a few days in advance. Eventually, the flood occurred in the urban area of Pescara, causing extensive damages. Similarly, the acqua alta (high water) events that occurred over the Venice Lagoon were forecast by the hydro-meteo-marine chains (SIMM and KASSANDRA) for IOP16 and IOP18. Moreover, three events are investigated using both measurements and model output. They are chosen because of the diversity and density of measurements and because each of them affected one of the three Italian hydro-meteorological sites: IOP2 occurred over NEI, IOP13 over CI and IOP19 over LT.

IOP2 occurred on 12 September 2012, producing several thunderstorms and a supercell. The storms produced heavy precipitation exceeding $50 \mathrm{~mm} \mathrm{~h}^{-1}$ and hail. The triggering and the intensification of the cell, turning into a supercell, seem to be related to the southerly low-level flow advecting moist air from the Adriatic Sea. The main characteristics of the cells were detected by operational radars, whereas the ATR42 flight detected the southerly flow advecting moist air at low levels. High-resolution models caught the main features of the storms, but failed to produce the very exact evolution of all the convective systems. Measurements and wind forecasts suggest the convergence of the southerly flow, with the downdraft of one of the cells as the main mechanism responsible for supercell development.

The analysis of this event suggests a few difficulties in correctly forecasting the two storms by both models, WRFARW and MOLOCH. The data recorded by the ATR42 may help in investigating the weather forecast models' ability to reproduce the sea surface fluxes, which is one of the energy sources of this event. Similarly, the radar data and/or the extra radio soundings may be assimilated to improve the initial conditions. These may be the topics of a future work aimed at improving the weather forecasts.

IOP13 occurred on 15-16 October 2012, producing a convective SW-NE oriented line crossing the city of Rome. The event was characterized by a deep upper-level trough and cyclogenesis over the Gulf of Genoa. The entrance of a southwesterly low-level jet advecting warm and humid air and the convergence with the westerly flow triggered the convective line. Moderate precipitation was recorded at several stations, with an increase in the rain rate $\left(35 \mathrm{~mm} \mathrm{~h}^{-1}\right)$ at the passage of the convective line. Both operational and research radars documented the event well. Moreover, Polar 55C radar operated at fixed azimuth and a variable elevation angle along the F20 flight, operating together with the RASTA radar onboard F20. Also in this case, the models forecast both the convergence line and the accumulated precipitation well.

The nonconventional data recorded by the radars and the disdrometer during this IOP may be used for improving the weather forecasts in different ways: tuning of the hydrometeor microphysics parameterization (as the size distribution parameters); and assimilating radar reflectivity and radial velocity from the radar.

IOP19 occurred on 4-5 November 2012, producing heavy precipitation between Liguria and Tuscany. The event was characterized by orographic precipitation reaching a maximum of $220 \mathrm{~mm} / 24 \mathrm{~h}$ over the Apuan Alps and $130 \mathrm{~mm} / 24 \mathrm{~h}$ over the Apennines. Also in this case, a strong southwesterly low-level jet advecting humid air and destabilizing the lower atmosphere was the most important feature. The model reproduced the thermodynamics of the event and the accumulated precipitation well. The comparison between all the available models highlights problems in the correct reproduction of orographic precipitation being strongly driven by the highest peak. Moreover, the spread in the location of the precipitation produced by the models was very small as well for the amount of precipitation, allowing for a strongly reliable forecast.

Also for this event, the data from the Falcon may be used either for understanding the local dynamics, as for example was done in this study by analyzing the dropsondes, or for improving the forecast by assimilating these data into the initial conditions. Moreover, the data from the PBL balloon could be assimilated to improve the initial conditions and thereby improve the forecast. An improved ability to reproduce the convergence (and therefore the precipitation) is expected. As for the previous event, radar data may also be assimilated.

It is noteworthy that the instrumentation deployed during HyMeX SOP1 provides a wealth of unprecedented information for studying atmospheric processes, weather patterns, and NWP model parameterization over Italy. For example, the local wind structure often leading to a heavy precipitation event (HPE) in LT, as predicted by NWP, has been confirmed 
by the dropsondes released from the aircraft during IOP19. Similarly, the simultaneous radar observations from ground and aircraft provide information on the droplet microphysics and precipitation during IOP13. On the other hand, the availability of different operational weather forecasting chains allowed for the highlighting of similar model difficulties in spite of the different configurations employed.

Hence, this valuable data set, together with the observations collected over Europe from the other HyMeX partners during the entire SOP1, provides an inestimable source of knowledge for

- statistically evaluating the strengths and deficiencies of the deployed forecasting chains,

- improving models' initial conditions by performing data assimilation,

- investigating the dynamics and thermodynamics of the events.

All these points suggest that a lot of work is still necessary to achieve a good forecast.

Finally, there are two important lessons from the first HyMeX campaign from the Italian point of view: it is possible to establish a strong link between research and operational agencies (Davolio et al., 2014), and the different highresolution operational chains are a great aid to the forecaster.

Moreover, strict cooperation among the Italian community and scientists from other countries involved in $\mathrm{HyMeX}$ is expected in the future, as several Italian scientists are leading or contributing to the HyMeX Science Teams (ST), including ST Microphysics in precipitating systems, ST Studies of IOP precipitation events, ST Atmospheric convective-scale data assimilation and ensemble prediction and ST Sources and transport of water vapor. Finally, the collaborative effort within the Italian scientific and forecast communities is still going on with the aim of achieving a better understanding of the complex meteorology of the Mediterranean basin by analyzing the different model outputs and the data collected during SOP1.

Acknowledgements. This work is a contribution to the HyMeX program. The authors are grateful to the National Department of Civil Protection (DPC) for allowing access to the regional raingauge networks, radar composite images and DEWETRA visualization platform, and to the CIMA foundation for providing the HyMeX database with the raingauge data in a suitable format. Thanks to all the participants at the national operational center: CNR (ISAC, IBIMET, IMAA), CETEMPS, Università La Sapienza, ISPRA, Università Parthenope, OSMER-ARPA FVG, ARPA Piemonte, ARPAV, ARPA-SIMC, LaMMA, ARPAL, Centro Funzionale Abruzzo, Centro Funzionale Marche, Centro Funzionale Umbria. The authors acknowledge the NASA Global Precipitation Measurement (GPM) mission ground validation (GV) program under Matthew Schwaller and Walter A. Petersen, GPM GV manager and science manager, for providing instruments for the HyMeX SOP1 field campaign, and Arthur Hou (deceased), former GPM project scientist, for his vision throughout the GPM core-satellite pre-launch activities. The authors wish to thank Marios Anagnostrou and John Kalogiros (NOA) for deploying instrumentation in Italy. We are also grateful to Dr. Stefano Dietrich and Dr. Marco Petracca (CNR ISAC, Rome branch) for creating and providing the LINET data images. Thanks to CESI-SIRF for the lightning data over FVG. Thanks to A. Cicogna (OSMER ARPA FVG) for his graphic support.

Edited by: H. Cloke

\section{References}

AdriaRadNet REPORT ACTION 3.1: Guidelines for hydrometeorological decision support system, available at: http://cetemps.aquila.infn.it/images/documenti/Adriaradnet/ Adriaradnet_WP3ReportAction31.pdf, 2013.

Barbi, A., Monai, M., Racca, R., and Rossa, A. M.: Recurring features of extreme autumnall rainfall events on the Veneto coastal area, Nat. Hazards Earth Syst. Sci., 12, 2463-2477, doi:10.5194/nhess-12-2463-2012, 2012.

Benzi, R., Fantini, M., Mantovani, R., and Speranza, A.: Orographic cyclogenesis in a saturated atmosphere and intense precipitation: baroclinic modal solutions under the joint action of localized mountains and humidity, Ann. Geophys., 40, 1579-1590, 1997, http://www.ann-geophys.net/40/1579/1997/.

Betz, H. B., Schmidt, K., Laroche, P. Blanchet, P., Oettinger, W. P., Defer, E., Dziewit, Z., and Konarski, J.: LINET - An international lightning detection network in Europe, Atmos. Res., 91, 564-573, doi:10.1016/j.atmosres.2008.06.012, 2009.

Bresson, E., Ducrocq, V., Nuissier, O., Ricard, D., and de SaintAubin, C.: Idealized numerical simulations of quasi-stationary convective systems over the northwestern Mediterranean complex terrain, Q. J. Roy. Meteor. Soc., 138, 1751-1763, 2012.

Buzzi, A., Fantini, M., Malguzzi, P., and Nerozzi, F.: Validation of a limited area model in cases of Mediterranean cyclogenesis: Surface fields and precipitation scores, Meteor. Atmos. Phys., 53, 53-67, 1994.

Buzzi, A., Davolio, S., and Malguzzi, P.: Heavy rainfall episodes over Liguria: elements controlling forecast errors of quantitative precipitation. Proc. of the 14thEGU Plinius Conf. on Mediterranean Storms and MEDEX Final Conf., Palma de Mallorca (Spain), 13-15 November, 2012.

Calas, C., Kreitz, M., and Chabot, E.: Large scale atmospheric conditions for HyMeX 2012-2013 SOP1 and SOP2. SOP Debriefing workshop, 15-17 April, 2013, Tolouse (FR), available at: www.hymex.org, 2013.

Casaioli, M., Coraci, E., Mariani, S., Ferrario, M. E., Sansone, M., Davolio, S., Cordella, M., Manzato, A., Pucillo, A., and Bajo, M.: The impact of different NWP forecasting systems on acqua alta forecasts: two IOP case studies over the NEI target site, 7th HyMeX Workshop, 7-10 October 2013, Cassis, France, 2013a.

Casaioli, M., Mariani, S., Malguzzi, P., and Speranza, A.: Factors affecting the quality of QPF: A multi-method verification of multi-configuration BOLAM reforecasts against MAP DPHASE observations, Meteor. Appl., 20, 150-163, 2013b. 
Coppola, E., Tomassetti, B., Mariotti, L., Verdecchia, M., and Visconti, G.: Cellular automata algorithms for drainage network extraction and rainfall data assimilation, Hydrol. Sci. J., 52, 579592, 2007.

Davolio, S., Mastrangelo, D., Miglietta, M. M., Drofa, O., Buzzi, A., and Malguzzi, P.: High resolution simulations of a flash flood near Venice, Nat. Hazards Earth Syst. Sci., 9, 1671-1678, doi:10.5194/nhess-9-1671-2009, 2009.

Davolio, S., Ferretti, R., Baldini, L., Casaioli, M., Cimini, D., Ferrario, M. E., Gentile, S., Loglisci, N., Maiello, I., Manzato, A., Mariani, S., Marsigli, C., Marzano, F. S., Miglietta, M. M., Montani, A., Panegrossi, G., Pasi, F., Pichelli, E., Pucillo, A., and Zinzi, A.: The role of the Italian scientific community in the first HyMeX SOP: an outstanding multidisciplinary experience, Bull. Am. Meteorol. Soc., submitted, 2014.

Drobinski, P., Ducrocq, V., Alpert, P., Anagnostou, E., Beìranger, K., Borga, M., Braud, I., Chanzy, A., Davolio, S., Delrieu, G., Estournel, C., Filali Boubrahmi, N., Font, J., Grubisic, V., Gualdi, S., Homar, V., Ivancan-Picek, B., Kottmeier, C., Kotroni, V., Lagouvardos, K., Lionello, P., Llasat, M. C., Ludwig, W., Lutoff, C., Mariotti, A., Richard, E., Romero, R., Rotunno, R., Roussot, O., Ruin, I., Somot, S., Taupier-Letage, I., Tintore, J., Uijlenhoet, R., and Wernli, H.: HyMeX, a 10-year multidisciplinary program on the Mediterranean water cycle, Bull. Am. Meteorol. Soc., doi:10.1175/BAMS-D-12-00242.1, in press, 2013.

Drofa, O. V. and Malguzzi, P.: Parameterization of microphysical processes in a non hydrostatic prediction model, Proc. 14th Intern. Conf. on Clouds and Precipitation (ICCP), Bologna, 19-23 July 2004, 1297-3000, 2004.

Ducrocq, V., Nuissier, O., Ricard, D., Lebeaupin, C., and Thouvenin, T.: A numerical study of three catastrophic precipitating events over southern France. Part II: Mesoscale triggering and stationarity factors, Q. J. Roy. Meteor. Soc., 134, 131-145, 2008.

Ducrocq, V. O. Roussot, K.Beranger, I. Braud, A. Chanzy, G. Delrieu, P. Drobinski, C. Estournel, B. Ivancan-Picek, S. Josey, K. Lagouvardos, P. lionello, M.C. Llasat, W. Ludwig, C. Lutoff, A. Mariotti, A. Montanari, E. Richard, R. Romero, I. Ruin, S. Somot: HyMeX Science Plan, Version 2.3.2, September 2010, available at: http://www.hymex.org/public/documents/HyMeX_ Science_Plan.pdf, 2010.

Ducrocq, V., Braud, I., Davolio, S., Ferretti, R., Flamant, C., Jansa, A., Kalthoff, N., Richard, E., Taupier-Letage, I., Ayral, P.-A., Belamari, S., Berne, A., Borga, M., Boudevillain, B., Bock, O., Boichard, J.-L., Bouin, M.-N., Bousquet, O., Bouvier, C., Chiggiato, J., Cimini, D., Corsmeier, U., Coppola, L., Cocquerez, P., Defer, E., Drobinski, P., Dufournet, Y., Fourrieì, N., Gourley, J. J., Labatut, L., Lambert, D., Le Coz, J., Marzano, F. S., Moliniè̀, G., Montani, A., Nord, G., Nuret, M., Ramage, K., Rison, B., Roussot, O., Said, F., Schwarzenboeck, A., Testor, P., Van Baelen, J., Vincendon, B., Aran, M., and Tamayo, J.: HyMeXSOP1, the field campaign dedicated to heavy precipitation and flash flooding in the northwestern Mediterranean, Bull. Am. Meteorol. Soc., doi:10.1175/BAMS-D-12-00244.1, in press, 2014.

Duffourg, F. and Ducrocq, V.: Origin of the moisture feeding the Heavy Precipitating Systems over Southeastern France, Nat. Hazards Earth Syst. Sci., 11, 1163-1178, doi:10.5194/nhess-111163-2011, 2011.
Duffourg, F. and Ducrocq, V.: Assessment of the water supply to Mediterranean heavy precipitation: a method based on finely designed water budgets, Atmos. Sci. Lett., 14, 133-138, doi:10.1002/asl2.429, 2013.

Ferrarin, C., Bajo, M., Roland, A., Umgiesser, G., Cucco, A., Davolio, S., Buzzi, A., Malguzzi, P., and Drofa, O.: Tide-surge-wave modelling and forecasting in the Mediterranean Sea with focus on the Italian coast, Ocean Modell., 61, 38-48, 2012.

Ferretti, R., Panegrossi, G., Rotunno, R., Pichelli, E., Marzano, F. S., Dietrich, S., Picciotti, E., and Vulpiani, G.: An analysis of three disastrous rain events occurred in Italy: Rome, Cinque Terre and Genoa, Proc. of the 14th EGU Plinius Conf. on Mediterranean Storms and MEDEX Final Conf., Palma de Mallorca (Spain), 13-15 November, 2012.

Guzzetti, F., Stark. C. P., and Salvati, P.: Evaluation of flood and landslide risk to the population of Italy, Environ. Manage., 36, 15-36, 2005.

Inghilesi, R., Catini, F., Bellotti, G., Franco, L., Orasi, A., and Corsini, S.: Implementation and validation of a coastal forecasting system for wind waves in the Mediterranean Sea, Nat. Hazards Earth Syst. Sci., 12, 485-494, doi:10.5194/nhess-12-4852012, 2012.

Kain, J. S.: The Kain-Fritsch convective parameterization: an update, J. Appl. Meteorol., 43, 170-181, 2004.

Kerkmann, J., Setvák, M., and Manzato, A.: Experimental 2.5minute super rapid scans from MSG-3 capture a supercell storm above northern Italy (12 September 2012), EUMETSAT report, 2012, available at: http://oiswww.eumetsat.org/WEBOPS/iotm/ iotm/20120912_convection/20120912_convection.html, 2012.

Lastoria, B., Simonetti, M. R., Casaioli, M., Mariani, S., and Monacelli, G.: Socio-economic impacts of major floods in Italy from 1951 to 2003, Adv. Geosci., 7, 223-229, 2006, http://www.adv-geosci.net/7/223/2006/.

Malguzzi, P. and Tartaglione, N.: An economical second-order advection scheme for numerical weather prediction, Q. J. Roy. Meteorol. Soc., 125, 2291-2303, 1999.

Malguzzi, P., Grossi, G., Buzzi, A., Ranzi, R., and Buizza, R.: The 1996 "century" flood in Italy. A meteorological and hydrological revisitation, J. Geophys. Res., 111, D24106, doi:10.1029/2006JD007111, 2006.

Mariani, S., Casaioli, M., Lanciani, A., Tartaglione, N., and Accadia, C.: A multi-method intercomparison approach for precipitation fields modelled by LAMs in the Alpine area: Two FORALPS case studies, Meteorol. Atmos. Phys., 103, 79-92, 2009.

Mariani, S., Casaioli, M., and Malguzzi, P.: Towards a new BOLAM-MOLOCH suite for the SIMM forecasting system: implementation of an optimised configuration for the HyMeX Special Observation Periods, Nat. Hazards Earth Syst. Sci. Discuss., 2, 649-680, doi:10.5194/nhessd-2-649-2014, 2014.

Marsigli, C., Montani, A., and Paccagnella, T.: Test of a COSMO-based convection-permitting ensemble in the Hymex framework, COSMO Newsletter No. 13, available at: http://www.cosmomodel.org/content/model/documentation/ newsLetters/newsLetter13/default.htm, 2013.

Melani, S., Pasi, F., Gozzini, B., and Ortolani, A.: A four year (2007-2010) analysis of long-lasting deep convective systems in the Mediterranean basin, Atmos. Res., 123, 151-166, 2012. 
Meischner, P. F., Bringi, V. N., Heimann, D., and Höller, H.: A squall line in southern Germany: Kinematics and precipitation formation as deduced by advanced polarimetric and Doppler radar measurements, Mon. Weather Rev., 119, 678-701, 1991.

Miglietta, M. M. and Rotunno, R.: Application of theory to observed cases of orographically forced convective rainfall, Mon. Weather Rev., 140, 3039-3053, 2012.

Montani, A., Cesari, D., Marsigli, C., and Paccagnella, T.: Seven years of activity in the field of mesoscale ensemble forecasting by the COSMO-LEPS system: main achievements and open challenges, Tellus A, 63, 605-624, 2011.

Parodi, A., Boni, G., Ferraris, L., Siccardi, F., Pagliara, P., Trovatore, E., Foufoula-Georgiou, E., and Kranzlmueller, D.: The "perfect storm": From across the Atlantic to the hills of Genoa, Eos Trans. AGU, 93, 225-226, 2012.

Protat, A., Bouniol, D., Delanoë, J., May, P. T., Plana-Fattori, A., Hasson, A., O'Connor, E., Görsdorf, U., and Heymsfield, A. J.: Assessment of CloudSat reflectivity measurements and ice cloud properties using ground-based and airborne cloud radar observations, J. Atmos. Ocean. Technol., 26, 1717-1741, 2009.

Rebora, N., Molini, L., Casella, E., Comellas, A., Fiori, E., Pignone, F., Siccardi, F., Silvestro, F., Tanelli, S., and Parodi, A.: Extreme rainfall in the Mediterranean: what can we learn from observations?, J. Hydrometeorol., 14, 906-922, 2013.

Rotunno, R. and Ferretti, R.: Mechanisms of intense Alpine rainfall, J. Atmos. Sci., 58, 1732-1749, 2001.

Rotunno, R. and Houze, R. A.: Lessons on orographic precipitation from the Mesoscale Alpine Programme, Q. J. Roy. Meteor. Soc., 133, 811-830, 2007.

Salvati, P., Bianchi, C., Rossi, M., and Guzzetti, F.: Societal landslide and flood risk in Italy, Nat. Hazards Earth Syst. Sci., 10, 465-483, doi:10.5194/nhess-10-465-2010, 2010.

Silvestro, F., Gabellani, S., Giannoni, F., Parodi, A., Rebora, N., Rudari, R., and Siccardi, F.: A hydrological analysis of the 4 November 2011 event in Genoa, Nat. Hazards Earth Syst. Sci., 12, 2743-2752, doi:10.5194/nhess-12-2743-2012, 2012.

Skamarock, W. C., Klemp, J. B., Dudhia, J., Gill, D. O., Barker, D. M., Duda, M. G., Huang, X. Y., Wang, W., and Powers, J. G.: A Description of the Advanced Research WRF Version 3, NCAR TECHNICAL NOTE, NCAR/TN-475+STR, 125 pp., 2008.
Speranza, A., Accadia, C., Mariani, S., Casaioli, M., Tartaglione, N., Monacelli, G., Ruti, P. M., and Lavagnini, A.: SIMM: An integrated forecasting system for the Mediterranean area, Meteor. Appl., 14, 337-350, 2007.

Steppeler, J., Doms, G., Schättler, U., Bitzer, H. W., Gassmann, A. Damrath, U., and Gregoric, G.: Meso-gamma scale forecasts using nonhydrostatic model LM, Meteorol. Atmos. Phys., 82, 7596, 2003.

Tartaglione, N., Maugeri, M., Dalan, F., Brunetti, M., Nanni, T., and Speranza, A.: Searching for resemblance between large-scale sea level pressure patterns leading to "intense" precipitation events over Italy, Theor. Appl. Climatol., 95, 183-196, 2009.

Thompson, G., Field, P. R., Rasmussen, R. M., and Hall, W. D.: Explicit forecast of winter precipitation using an improved bulk microphysics scheme. Part II: Implementation of a new snow parameterization, Mon. Weather Rev., 136, 5095-5115, 2008.

Tibaldi, S., Buzzi, A., and Speranza, A.: Orographic cyclogenesis, in: The Erik Palmen Memorial Volum, edited by: Newton, C. and Holopainen, E. O., American Meteorological Society, Boston, 107-127, 1990.

Tomassetti, B., Ferretti, R., Pichelli, E., Lombardi, A., Gentile, S., Cerasani, E., Colaiuda, V., Maiello, I., and Verdecchia, M.: An operational chain for flood alert mapping, in preparation, 2014.

Umgiesser, G., Melaku Canu, D., Cucco, A., and Solidoro, C.: A finite element model for the Venice Lagoon. Development, set up, calibration and validation, J. Mar. Syst., 51, 123-145, 2004.

Vulpiani, G., Montopoli, M., Delli Passeri, L., Gioia, A. G., Giordano, P., and Marzano, F. S.: "On the use of dualpolarized C-band radar for operational rainfall retrieval in mountainous areas", J. Appl. Meteorol. Climatol., 51, 405-425, doi:10.1175/JAMC-D-10-05024.1, 2012.

Weisman, M. L., Davies, C., Wang, W., Manning, K. W., and Klemp, J. B.: Experiences with 0-36-h explicit convective forecasts with the WRF-ARW model, Weater Forecast., 23, 407-437, 2008. 